Pol. J. Food Nutr. Sci., 2021, Vol. 71, No. 1, pp. 5-20

On-line ISSN: 2083-6007

Print ISSN: $1230-0322$

DOI: $10.31883 /$ pjfns/132853 http://journal.pan.olsztyn.pl

Review article

Section: Food Quality and Functionality

\title{
Recent Advances in Biotechnological Methods for Wheat Gluten Immunotoxicity Abolishment - a Review
}

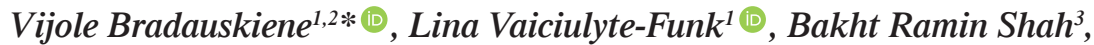 \\ Darius Cernauskas $^{1}{ }^{\odot}$, Mihaela Adriana Tita ${ }^{4}$
}

\author{
${ }^{1}$ Food Institute, Kaunas University of Technology, Radvilenu road 19C-413, Kaunas, Lithuania \\ ${ }^{2}$ Food Technology Department, Klaipeda State University of Applied Sciences, Bijunu street 10-223, Klaipeda, Lithuania \\ ${ }^{3}$ Institute of Aquaculture and Protection of Waters, Faculty of Fisheries and Protection of Waters, \\ South Bohemian Research Center of Aquaculture and Biodiversity of Hydrocenoses, \\ University of South Bohemia in Ceske Budejovice, Na Sádkách 1780, 370 05, České Budějovice, Czech Republic \\ ${ }^{4}$ Faculty of Agricultural Sciences, Food Industry and Environmental Protection, \\ Lucian Blaga University of Sibiu, Ion Ratiu street 5-7, Sibiu, România
}

Key words: celiac disease, wheat immunogenicity, detoxified wheat, gluten hydrolysis

Due to the increasing incidence of gluten intolerance, researchers are focusing on finding ways to eliminate immunotoxicity of wheat, this would allow the use of wheat products for gluten-intolerant consumers. The article reviews recent studies on biotechnological methods to eliminate and reduce the immunogenicity of wheat products. So far, many gluten removal methods have been proposed, but their efficacy levels were quite different. Enzymatic treatment of gluten fragments can be considered the simplest and non-invasive tool to eliminate the toxicity of gliadins and glutenins. For this purpose, various endogenous enzymes derived from cereals, and also those of bacterial, fungal, plant, and animal origin can be used in food processing. Some of the enzymes hydrolyze gluten, others block the action of toxic protein fragments. The majority of studies were carried out using lactic acid bacteria cultures, as single strains or in consortia. Satisfactory results have been achieved using bacterial and plant enzymes, but the complete elimination of gluten immunogenicity is still possible by using fungal proteases, engineered enzymes or combining several treatments, for example, by using lactic acid fermentation or germination with fungal proteases. However, the question of how degradation of gluten affects the quality of flour (dough) in practice remains unanswered. It is not clear whether the products of such wheat flour are better and safer than those made from starches and whether their price and quality are acceptable to consumers. The insights presented in this review will be helpful to other researchers and cereal-based food producers in choosing ways to reduce gluten immunogenicity.

\section{ABBREVIATIONS}

CD: coeliac disease; GF: gluten-free; GFD: gluten-free diet; HLA: human leukocyte antigen; LAB: lactic acid bacteria; NCGS: non-coeliac gluten sensitivity; PEP: prolyl endopeptidase; WA: wheat allergies.

\section{INTRODUCTION}

Wheat and other grains are one of the most important components of human nutrition on a global scale, and total wheat consumption has increased in recent years [FAOSTAT: Production/Yield quantities of Wheat in World, 2020]. However, for a large number of consumers, wheat gluten proteins cause severe intolerance, manifested by allergic reactions. Gliadins and glutenins are fractions of the immunogenic gluten protein [Giménez et al., 2019]. These toxic proteins can

\footnotetext{
* Corresponding author: Tel.: +37067107872;

E-mail: vijole.bradauskiene@ktu.edu (V. Bradauskiene)
}

cause wheat allergies (WA) and development of coeliac disease (CD) in some consumers [Navarro et al., 2017]. CD is one of the most common diseases associated with food intolerance and its prevalence in the world is increasing [King et al., 2020]. CD is more pronounced for genetically predisposed people as an inflammatory disease of the upper small intestine. The manifestation of the disease is determined by glutamine- and proline-containing cereal gluten peptides, most of them with a minimum length of nine amino acids [Bromilow et al., 2017]. During digestion, these peptides are not sufficiently digested by digestive enzymes (pepsin, chymotrypsin, trypsin); they reach lymphatic tissue, meet antigenic cells HLA-DQ2 and HLA-DQ8, specific for coeliac disease, and stimulate intestinal T-cells. Typical clinical signs for CD are flat intestinal mucosa and malabsorption [McAllister et al., 2019]. In addition, an increasing number of cases of non-coeliac gluten sensitivity (NCGS) have been reported in consumers without CD or WA (gliadin does not cause mucosal inflammation of mucous membrane) [Catassi et al., 2015; Lionetti et al., 2017]. These cases are manifested by irritation 
of the intestines and other symptoms associated with the use of gluten-containing foods [Tanveer \& Ahmed, 2019].

According to the latest scientific data, the life-long (permanent) gluten-free diet (GFD) is an effective treatment for CD. This diet is popular among consumers with NCGS, and also among people who do not experience CD, but are seeking favorable health effect from consumption of a GFD [Krigel \& Lebwohl, 2016]. Consumers seeking GFD face many challenges associated with cross-contamination, lack of clarity in food labeling policies, poor quality of gluten-free (GF) products, and higher prices compared to gluten-containing foods [Do Nascimento et al., 2017; Estévez et al., 2016]. Nutrition of GFD-compliant consumers is unbalanced, leading to a higher percentage of calories from fat and less from carbohydrates. In addition, there was found a deficiency of non-starch polysaccharides [Hopkins \& Soon, 2019], which are very important for reducing the risk factors for developing chronic diseases and certain types of oncological diseases [Lovegrove et al., 2017]. GF products introduced in the market have a poorer taste than regular products, and may cause a nutritional deficiency among consumers due to the unbalanced composition of nutrients [Stantiall \& Serventi, 2018]. Examination of patients with CD showed that those with the same energy intake as the control group had a lower intake of fiber, vitamin A, B-group vitamins: $\mathrm{B}_{6}, \mathrm{~B}_{12}$, folic acid, thiamine and minerals: calcium, phosphorus, magnesium, and iron [Pellegrini \& Agostoni, 2015; Vici et al., 2016]. Zinc and selenium deficiency may be also associated with the elimination of cereals from the diet [Stazi \& Trinti, 2008; Tran et al., 2011]. Bread and other products made from naturally gluten-free raw materials such as: buckwheat, rice, corn, quinoa, sorghum, or teff flours, often have lower textural and sensory properties compared to the corresponding gluten-containing bread products [Naqash et al., 2017]. The GF products usually have a high glycemic index [Vici et al., 2016], which is associated with an increased risk of obesity among consumers with CD. The increasing demand for high-quality GF bakery products leads to the search for new approaches in GF food producing. The production of nutritionally-balanced GF products is an important social and economic issue. To solve it, new strategies are being searched for to remove immunogenicity from wheat and other cereals and produce balanced, sensorially-acceptable to consumer products.

The diet should not only be gluten-free but also health-friendly to avoid nutritional imbalances [Chishty \& Singh, 2017]. The setup of application of biotechnological tools based on enzyme treatments is an active field of research that may provide new possibilities to GF wheat product development. For products used in GFD, it is necessary to remove or degrade wheat prolamins that are harmful to gluten-non-tolerant users. Studies related to the elimination of gluten from wheat processing products by using biological methods have been performed [Scherf et al., 2018]. Unfortunately, there is a lack of scientific information about the efficiency of biological measures on different conditions, as well as on the possibilities of implementing these methods in the production of wheat products in order to modify their chemical composition and effectively eliminate gluten residues to improve product absorption.
The aim of this review article is to analyze the biotechnological methods for the elimination / reduction of immunogenicity of wheat products and evaluate the possibilities of their implementation. The insights of this review will be helpful to other researchers and wheat producers to choose ways for gluten immunotoxicity abolishment. The threshold set by the Codex Alimentarius [Standard 118-1979] for a gluten-free food claims at $20 \mathrm{mg}$ gluten/ $\mathrm{kg}$ product. However, despite the fact that manufacturers are subject to strict regulations, even consumers, who adher to GFD, were reported to consume more than the tolerable amount of gluten because of the contamination of products and inaccurate labeling [Bruins Slot et al., 2015]. Therefore, it is desirable to provide safe GF foods with a gluten level as low as possible. A reduction of the immunoreactivity of food proteins can be achieved by proteolysis occurring in food and degrading the immunoreactive protein fragments [El-Ghaish et al., 2011].

\section{CLASSIFICATION OF BIOTECHNOLOGICAL MEASURES FOR GLUTEN HYDROLYSIS}

Over the last decade, the use of biological measures in wheat products to eliminate or reduce the immunotoxicity of gluten proteins is being actively studied. Various enzymes such as those of bacterial, fungal, plant, and animal origin as well as recombinant enzymes expressed in microbial systems were investigated. The scheme of the sources of enzymes used for gluten hydrolysis, thus eliminating or reducing the gluten immunotoxicity, is shown in Figure 1.

Gluten can be hydrolyzed either by individual enzymes or by combining different biological measures [Scherf et al., 2018]. Enzymatic cleavage of gluten fragments is the easiest and non-invasive way to eliminate the toxicity of gliadins and glutenins. It can be applied in two ways. Firstly, in order to reduce the negative effects of gluten on patients with CD, enzymes should be taken with food [Janssen et al., 2015]. Secondly, the toxic effects of gluten can be eliminated before consumption during food processing [Jouanin et al., 2018].

\section{POTENTIAL OF DIFFERENT ENZYMES TO ELIMINATE GLUTEN IMMUNOGENICITY}

Different peptidases can be used to degrade gliadins and glutenins in food products [Wieser \& Koehler, 2012]. Endoproteases attack internal peptide bonds, while exoproteases attack only the N-terminal (aminopeptidases) or C-terminal (carboxypeptidases) forms.

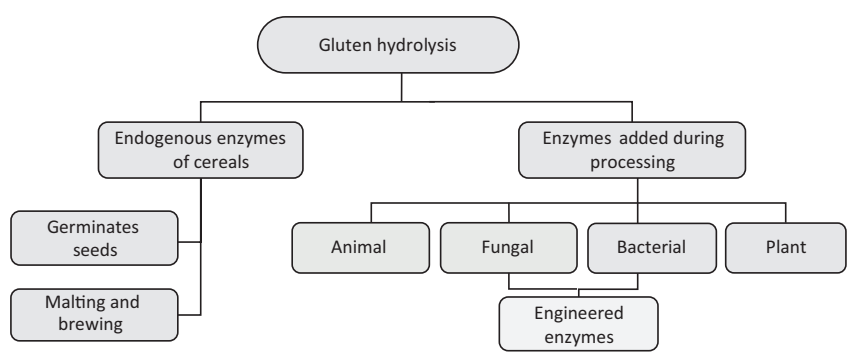

FIGURE 1. Sources of enzymes used for gluten hydrolysis. 
TABLE 1. Cereal endogenous enzymes used for gluten hydrolysis.

\begin{tabular}{lcc}
\hline Source of enzymes & Results & References \\
\hline Germinating grains & Hydrolysis of prolamines. & Hartmann et al. [2006] \\
Proteases from germinating cereals & Hydrolysis of prolamines. & Stenman et al. [2009] \\
Wheat grains germinated for 8 days & Reduction of peptides eliciting immune response. & Boukid et al. [2017b] \\
Wheat kernels after 7-day germination & Degradation of gluten. & Michalcová et al. [2019] \\
Germination of wheat kernels & Gluten content in wheat germ (8-10 days) & Adrianos et al. [2017] \\
Recombinant wheat cysteine protease Triticain- $\alpha$ & was lower than the limit of detection. \\
Cysteine protease EP-B2 from germinated barley & Triticain- $\alpha$ activated proteolytic enzymes in vitro. & Savvateeva et al. [2015] \\
\hline
\end{tabular}

\section{Endogenous enzymes from cereals}

Proteases are often synthesized as inactive specific proteases which are activated under the appropriate conditions of temperature, humidity, etc. One way to activate endoprotease is grain germination. Although this measure is mainly applied to barley - in the malt preparation and beer production [Guerdrum \& Bamforth, 2012; Kerpes et al., 2016; Knorr et al., 2016], the immunogenicity of wheat can also be reduced in a similar way. Studies in which gluten is hydrolyzed by endopeptidases during grain germination are systematized in Table 1.

Hartmann et al. [2006] proved that after 2-h incubation $\left(37^{\circ} \mathrm{C}, \mathrm{pH} 6.5\right)$, the toxic wheat peptides were intensively degraded - peptides with more than eight amino acid residues were not detected. As Stenman et al. [2009] proved, the gluten content in specially prepared germinated wheat can be minimal. Michalcová et al. [2019] analyzed the conditions for digesting wheat gluten proteins by endoproteases during germination. In their experiment, the wheat kernels were germinated for up to 7 days at temperatures of $15-$ $30^{\circ} \mathrm{C}(\mathrm{pH} 3.0-8.0)$. The authors observed gluten degradation that started after 3 days and lasted for up to 7 days. The lowest content of gluten proteins was measured on the $7^{\text {th }}$ day at a temperature of $20^{\circ} \mathrm{C}(\mathrm{pH}$ 5.5). In turn, Adrianos et al. [2017] showed that the gluten content of wheat sprouts (8-10 days) in all preparations was lower than the limit of detection for both ELISA (4 mg/kg) and the thresholds established by Codex Alimentarius [Standard 118 - 1979]; therefore, the sprouts could be classified as GF. Wheat sprouts are rich in nutrients that might be beneficial for consumers with malabsorption disorders. They can be used for juicing, added to cocktails, or consumed as wheat grain dietary supplements in tablets, capsules, and in the liquid form. An isolate from germinated cereals or purified enzymes can also be used for gluten hydrolysis. Experiments showed that germinated cereal proteases were capable of cleaving intact gluten proteins [Geßendorfer et al., 2011]. Schwalb et al. [2012] conducted studies on different germinated grain crops and identified their specific peptidase activity. The studies were performed with peptidase-enriched solutions. They were obtained by extraction from germinated, lyophilized, and milled grains. A synthetic $\alpha$-gliadin peptide was used as a peptide substrate. It was degraded under differ- ent conditions: $60-90 \mathrm{~min}$ at $40-50^{\circ} \mathrm{C}(\mathrm{pH} 4.0 ; 6.5)$. Peptide degradation was found to be more intense at $\mathrm{pH} 4.0$ than at pH 6.5. Peptide was degraded slowly and only about $30 \%$ was left after $90 \mathrm{~min}$. Germinating barley (Hordeum vulgare) seeds secrete an enzyme, cysteine protease, which hydrolyzes hordein, i.e. the barley analog of wheat gluten. This glutenase, named EP-B2, has good specificity for the immunotoxic wheat gluten amino acid sequences. Besides, it was found to be most active at low $\mathrm{pH}$, resistant to pepsin but digested at physiological concentrations of trypsin; therefore, it was proved be suitable for gluten hydrolysis [Diaz-Mendoza et al., 2019]. Kiyosaki et al. [2009] and Savvateeva et al. [2015] studied abilities of recombinant wheat cysteine protease - Triticain- $\alpha$ to activate proteolytic enzymes (glutenase and collagenase) in vitro, which are optimally active at $37^{\circ} \mathrm{C}$. Mass-spectrometry analysis showed that Triticain- $\alpha$ degraded immunotoxic peptides. Studies have shown that Triticain- $\alpha$ has a high glutenase activity under normal human physiological conditions $\left(37^{\circ} \mathrm{C}\right)$ and can, therefore, be used in CD treatment.

Generally, proteases from germinated cereals can significantly reduce the amounts of toxic gluten proteins or peptides. Therefore, they may be used in a variety of areas: food supplements that help the body digest gluten without allergic reactions, as well as in the production of special foods for CD patients [Adrianos et al., 2017]. The quality and nutritional value of wheat products can be improved by choosing the optimal duration and conditions of grain germination [Ding et al., 2018], because by germinating wheat grains for up to $48 \mathrm{~h}$, it is possible to bake improved-quality bread that will not be GF even though the rheological properties of the dough are poorer [Baranzelli, 2018; Cardone et al., 2020]. Long-term germination increases the activity of $\alpha$-amylase (breaks down starch), can significantly reduce the quality of flour and the baking process: lower falling numbers can affect mixability, crumb strength, and loaf specific volume and sliceability [Thomason et al., 2019]. Therefore, germination of wheat is a complex way to eliminate gluten from baked goods. Such detoxified wheat can only be used to supplement GF products, while in the production process it is easier to use the isolate from sprouted cereal grains or purified enzymes. 


\section{Bacterial enzymes}

\section{Fermentation with probiotic strains}

The most common way of applying bacterial enzymes is fermentation with Lactobacillus strains. Lactic acid bacteria (LAB) fermentation can improve the texture and palatability of various types of foods (whole grains, fiber-rich, gluten-free), stabilize or increase the amount of various biologically-active compounds, retard starch bioavailability, and improve mineral bioavailability [Katina et al., 2006]. LAB produce a variety of enzymes that degrade anti-nutritional compounds, thereby improving the texture of baked goods, ensuring the development of palatability and the formation of aromatic compounds, and prolonging the shelf life [Luz et al., 2019; Gobbetti et al., 2019; Sun et al., 2020]. Many studies have focused on the possibilities of probiotic strains to decrease the immunotoxicity of wheat products (Table 2). The main idea of those studies was to use bacterial enzymes during food processing to eliminate immunotoxic gliadins. Fermentation with LAB decreases the number of disulfide bonds in the gluten network, which causes an immune response in people with sensitivity to gluten [Gänzle et al., 2008]. Individual LAB species produce specific peptidases that are capable of hydrolyzing hardly degradable, immunoreactive, and coeliac disease-causing peptides [Vukotic et al., 2016]. It is important to select LAB strains with specific proteolytic effects for the successful breakdown of the gliadin complex structure [Stefańska et al., 2016].

The use of lactic acid cultures for the first time in the $21^{\text {st }}$ century aimed to remove traces of gluten fragments from processed foods. Di Cagno et al. [2002] showed that selected LAB with proteolytic activity can effectively hydrolyze the toxic gliadin peptides in wheat sourdough. As Di Cagno et al. [2004] proved, L. alimentarius 15M, L. brevis $14 G$, L. sanfranciscensis $7 A$, and L. hilgardii $51 B$ strains have peptidases capable of hydrolyzing all the different peptide bonds present in prolamins. The next study of Di Cagno et al. [2008] proved the effectiveness of selected LAB cultures to remove gluten residues and enhance the nutritional value of GF bread. Forty-six strains of LAB were tested for evaluating the proteolytic activity and medium acidification rate. Cultures of L. sanfranciscensis LS40 and LS41, and L. plantarum $C F 1$ were selected as the most suitable for the production of GF bread from pseudocereals with gluten addition. During fermenting the bread, the initial gluten content of $400 \mathrm{mg} / \mathrm{kg}$ was degraded to below $20 \mathrm{mg} / \mathrm{kg}$, and the content of free amino acids increased.

Several studies have also been carried out to assess the effectiveness of individual lactic acid cultures. Fermentation using L. sanfranciscensis [Thiele et al., 2004; Vermeulen et al., 2006] or L. plantarum [Gerez et al., 2008; Rollan et al., 2005; Yin et al., 2015] promoted hydrolysis and increased solubility of wheat proteins. It has been shown that protein hydrolysis in sourdough is predominantly associated with $\mathrm{pH}$-dependent activity of cereal enzymes and corresponding changes in proteolytic activity.

Several studies have been carried out to assess the effectiveness of the pool of selected probiotic lactobacilli. De Angelis et al. [2006] found the capacity of probiotic VSL\#3 prepara- tion to intensively hydrolyze wheat gliadins. Probiotic product VSL\#3 consisting of strains of Streptococcus thermophilus, L. plantarum, L. acidophilus, L. casei, L. delbrueckii spp. Bulgaricus, Bifidobacterium breve, B. longum, and B. infantis was used in the fermentation of wheat flour dough to reduce the content of immunotoxic fragments, to hydrolyze gliadin peptides, and to achieve almost complete hydrolysis of gliadin. Patent application WO2006 / 097415 [2006] describes a method for gluten degradation using a complex mixture of at least six lactic acid bacterial cultures and / or bifidobacteria and long fermentation time (24-31 h). After hydrolysis, non-degraded gliadins remained, some gliadins were partially hydrolyzed, and others were insensitive hydrolyzed; therefore, this method is not the most suitable for complete gluten degradation. L. plantarum CRL 775 and Pediococcus pentosaceus CRL 792 also hydrolyzed gliadins during the fermentation of wheat dough. The cleavage of gliadins obtained using cell extracts was higher than using cell suspensions [Gerez et al., 2012]. Romanová \& Urminská [2017] investigated growth characteristics of L. plantarum CCM 3627 and L. brevis CCM 1815 and the activity of aminopeptidases. In turn, Stefańska et al. [2016] investigated 11 LAB cultures that can hydrolyze gluten in baked goods. All sourdoughs have been found to contain some polypeptides with reactive epitopes. Two strains: Enterococcus mundtii and Wickerhamomyces anomalus, can be used as probiotics for leavening. E. mundtii QAUSD01 and $W$. anomalus QAUWAO3 demonstrated the ability to tolerate low $\mathrm{pH}$, resistance to bile salts, and hydrophobicity compared to other gluten-degrading yeast and bacterial strains. It is suitable to use them in cereal fermentation and, therefore, they can be used to produce bakery products for consumers with NCGS [Sakandar et al., 2018].

Sourdough-based biotechnology could contribute to the quality of life improvement in consumers suffering from $C D$ [Nionelli \& Rizzello, 2016]. However, this method is not suitable for complete gluten degradation. It is very important to select the optimally parameters of the fermentation process while preparing GF products. The results achieved in various studies showed that the proteolytic activity of the selected LAB strains was not high enough [Stefańska et al., 2016], long fermentation time worsened the technological properties of wheat bread [Katina et al., 2006], and that baked wheat products fermented with $\mathrm{LAB}$ were not safe for consumers with CD [Laatikainen et al., 2017]. Therefore, it is advisable to use these $\mathrm{LAB}$ to break down allergenic proteins in bakery products for consumers with $\mathrm{CD}$ in combination with other measures, and also to produce bakery products for consumers with NCGS [Sakandar et al., 2018].

\section{Prolyl endopeptidases from microorganisms}

A relatively new trend is gluten detoxification by breaking peptide bonds with prolyl endopeptidases (PEPs). PEPs are endoproteolytic enzymes secreted by microorganisms and plants. They hydrolyze gluten into smaller peptides that can be digested by intestinal enzymes or to amino acids [HerediaSandoval et al., 2016]. PEPs can be used as a dietary therapeutic tool for CD patients. The mechanism of their action is as follows: gluten is hydrolyzed by co-ingested peptidases in the consumer's stomach and stops (prevents) CD specific 
TABLE 2. Enzymes of bacterial origin for reducing gluten immunogenicity.

\begin{tabular}{|c|c|c|c|}
\hline Enzyme source & Enzyme/bacterial strain & Results & References \\
\hline \multirow{12}{*}{$\begin{array}{l}\text { Fermentation } \\
\text { with LAB } \\
\text { cultures }\end{array}$} & $\begin{array}{l}\text { L. alimentarius, } \text { L. brevis, } \\
\text { L. sanfranciscensis, L. hilgardii }\end{array}$ & Gluten degradation. & $\begin{array}{l}\text { Di Cagno et al. [2002]; } \\
\text { Di Cagno et al. [2004] }\end{array}$ \\
\hline & Probiotic product VSL \# 3 & Intense gliadin degradation. & $\begin{array}{l}\text { De Angelis et al. [2006]; } \\
\text { WO2006/097415 }\end{array}$ \\
\hline & L. sanfranciscensis & Gluten degradation. & $\begin{array}{l}\text { Thiele et al. [2004]; } \\
\text { Vermeulen et al. [2006] }\end{array}$ \\
\hline & 4 strains of $L$. plantarum & $\begin{array}{l}\text { Gluten degradation - hydrolysis } \\
\text { of wheat proteins. }\end{array}$ & $\begin{array}{l}\text { Gerez et al. [2008] } \\
\text { Rollan et al. [2005] }\end{array}$ \\
\hline & L. plantarum & Hydrolysis and solubilization of wheat proteins. & Yin et al. [2015] \\
\hline & $\begin{array}{l}47 \text { strains of LAB were tested for } \\
\text { evaluating proteolytic activity }\end{array}$ & Removed gluten residues in GF bread. & Giuliani et al. [2016] \\
\hline & L. plantarum and L. brevis & Active proline aminopeptidase was produced. & Romanová et al. [2017] \\
\hline & 13 strains of probiotic bacteria & Partial gluten degradation. & Stefanska et al. [2016] \\
\hline & 18 commercial strains of LAB & $\begin{array}{l}\text { The pool of LAB strongly } \\
\text { hydrolyzed gluten in bread. }\end{array}$ & Francavilla et al. [2017] \\
\hline & $\begin{array}{l}\text { Enterococcus Enterococcus and } \\
\text { Wickerhanomyces strains }\end{array}$ & LAB tolerated low $\mathrm{pH}$ and bile salts. & Sakandar et al. [2018] \\
\hline & $\begin{array}{l}12 \text { strains of LAB and yeasts isolated } \\
\text { from Chinese traditional sourdough }\end{array}$ & Its ability to degrade wheat protein was limited. & Fu et al. [2020] \\
\hline & $\begin{array}{l}\text { Bifidobacterium species: B. bifidum, } \\
\text { B. longum, } B \text {. breve and B. animalis }\end{array}$ & $\begin{array}{l}\text { Proteolysis of intact gluten proteins, } \\
\text { gliadins, and glutenins. }\end{array}$ & de Almeida et al. [2020] \\
\hline \multirow{7}{*}{$\begin{array}{l}\text { Enzymes of } \\
\text { bacterial origin }\end{array}$} & $\begin{array}{l}\text { Prolylendopeptidase (PEP) } \\
\text { from Myxococcus xanthus }\end{array}$ & $\begin{array}{l}\text { PEP reduces the amount of } \\
\text { immunoreactive gliadin peptides. }\end{array}$ & Alvarez-Sieiro et al. [2014] \\
\hline & $\begin{array}{c}\text { Proteases: Bacillus stearothermophilus, } \\
\text { B. thermoproteolyticus, Streptomyces } \\
\text { griseus, B. licheniformis }\end{array}$ & $\begin{array}{l}\text { B. licheniformis and } B \text {. thermoproteolyticus } \\
\text { work very effectively. }\end{array}$ & Socha et al. [2015] \\
\hline & $\begin{array}{l}\text { PEP from F. meningosepticum, } \\
\text { S. capsulata, M. xanthus and E. coli }\end{array}$ & PEP partially degraded gliadin peptides. & Moreno Amador et al. [2019] \\
\hline & Alcalase $2.4 \mathrm{~L}$ & $\begin{array}{l}\text { Effectively removes gluten } \\
\text { from unpurified starch. }\end{array}$ & Bassi [2016] \\
\hline & Alcalase $2.4 \mathrm{~L}$ & $\begin{array}{l}\text { Reduced the antigenicity of } \\
\text { wheat gluten hydrolysates. }\end{array}$ & Cruz-Chamorro et al. [2020] \\
\hline & $\begin{array}{c}\text { New E40 glutenase from Actinomycete } \\
\text { strain Actinoallomurus A8 }\end{array}$ & $\begin{array}{l}\text { Efficiently degrades the most } \\
\text { immune-toxic gluten. }\end{array}$ & Cavaletti et al. [2019] \\
\hline & Bacillus spp. isolated from sourdough & Reduced gluten content in wheat sourdough. & Rashmi et al. [2020] \\
\hline \multirow{3}{*}{$\begin{array}{l}\text { Engineered } \\
\text { enzymes }\end{array}$} & PEP enzyme of Sphingomonas capsulate & Effectively degraded CD-active peptides. & Ehren et al. [2008] \\
\hline & Peptidase Kuma030 & High activity of $99.97 \%$ gluten degradation. & Wolf et al. [2015] \\
\hline & Peptidase KumaMax or Kuma010 & $\begin{array}{l}116 \text { times higher proteolytic } \\
\text { activity compared to native. }\end{array}$ & Yoosuf \& Makharia [2019] \\
\hline \multirow{2}{*}{$\begin{array}{l}\text { Transglutaminase } \\
\text { (mTG) of } \\
\text { microbial origin }\end{array}$} & $\begin{array}{l}\text { Transamidation with mTG in the } \\
\text { presence of methyl ester of lysine }\end{array}$ & $\begin{array}{l}\text { Reduced the ability to induce an } \\
\text { immune response in vitro. }\end{array}$ & Luongo et al. [2020] \\
\hline & $\begin{array}{l}\text { MTG and chymotrypsin used to bind } \\
\text { lysine or valine to gluten proteins }\end{array}$ & $\begin{array}{l}\text { Reduced the specific immune } \\
\text { response of gliadin. }\end{array}$ & Zhou et al. [2017] \\
\hline
\end{tabular}

immune responses in the small intestine. Likewise, PEPs may be used to produce GF products from gluten-containing raw materials. Enzymatic therapy for coeliac disease is promising; however, it is important to select the most active enzymes [Boukid et al., 2017a]. Matysiak-Budnik et al. [2005] found that PEPs partially degraded gliadin peptides at low concentrations $(20 \mathrm{mU} / \mathrm{mL})$ both in vitro and ex vivo, but could not protect the intestines from immunotoxic metabolites. High levels of PEPs and a longer time (at least $500 \mathrm{mU} / \mathrm{mL}$ for $3 \mathrm{~h}$ ) were required for the complete detoxification of peptides. As Socha et al. [2015] proved, all the bacterial proteases of various origin were slightly different in the degree of proteolysis. B. licheniformis and B. thermoproteolyticus acted very effectively: molecular weight of fermentation products was low. The use of PEPs from $L$. case $i$ with conventional food was proposed as a treatment method for CD patients [Alvarez-Sieiro et al., 2014]. Bassi [2016] described a method to produce GF starch, where the mass of unpurified starch is treated with an agent to degrade gluten. It should be noted that the effective removal of gluten (even up to $470 \mathrm{mg} / \mathrm{kg}$ ) from starch can be achieved using Alcalase. Prolonged exposure to high concentrations of PEPs was shown to reduce the amount of immunoreactive gliadin peptides in wheat flours [Rashmi et al., 2020]. 


\section{Engineered enzymes}

An ideal peptidase for use in the oral enzymatic therapy should possess many qualities to meet high requirements of its application; therefore, it is unlikely that a single naturally occurring enzyme can afford this to the full extent. In a way to solve the problem, the computational protein design allows introducing new traits or significantly improve functional properties of native enzymes [Gordon et al., 2012]. Newly constructed enzymes, gluten hydrolases among them, exhibit higher specificity, much higher activity, solubility, and better performance in the required medium (for example, highly acidic environment of the stomach after meal) [Yoosuf \& Makharia, 2019].

First works were carried out in this respect by Ehren et al. [2009]. They aimed to develop PEPs with higher activity and stability under gastric conditions, taking a PEP of Sphingomonas capsulate as a native template enzyme. The enzyme with as much as $20 \%$ enhanced specific activity at $\mathrm{pH} 4.5$ and 200 -fold greater resistance to pepsin was created. However, this peptidase was reported to have low to negligible levels of catalytic activity in a lower $\mathrm{pH}$ (in the actual $\mathrm{pH}$ range of the stomach) and was, thus, expected to be effective only in the small intestine region.

Best described engineered enzymes for gluten hydrolysis are peptidases KumaMax and Kuma030. KumaMax was designed as the improvement of kumamolisin-As (KumaWT, EC 3.4.21), an acidic serine endopeptidase of an acidophilic bacterium Alicyclobacillus sendaiensis [Gordon et al, 2012]. The cleavage specificity of the catalytically-active site of $\mathrm{Ku}$ maWT was shifted to CD-active peptides. The KumaMax has more than 100-fold increased activity on the gluten tetrapeptide substrate. The next step in kumamolisin-As improvement was carried out using the same Rosetta Molecular Modeling Suite, which allowed redesign the active site of KumaMax [Wolf et al., 2015] to reach $>99 \%$ activity of the enzyme. The new enzyme was referred to as Kuma030. It is 44-fold more active against peptides containing PQQ, and 11-fold more active against peptides containing PQL, than KumaMax. Kuma030 effectively (99.97\%) degraded CD-active peptides in $30 \mathrm{~min}$. This enzyme could also be applicable for gluten removal during food processing. Though the newly designed enzymes are still waiting for the clinical studies, they look as promising measures for preventing CD effects.

\section{Transamidation with transglutaminase}

Enzymatic hydrolysis (during the production of wheat flour dough) involves the degradation of the wheat proteins, including highly immunotoxic ones, to those with CD. It completely destroys the gluten structure, and reduces the technological properties (elasticity) of the dough and baked goods. In manufacturing practice, these problems are dealt with by using flour structure enhancers (gelatinized starch), emulsifiers, and hydrocolloids. Therefore, the scientific community has a strong interest in finding alternative methods for gluten degradation: strategies are being developed to eliminate harmful gluten peptides from gluten-free products to counteract the immunogenic effects of gluten fragments, as well as strategies to block gluten-induced inflammatory response [Heredia-Sandoval, 2016]. The essence of this gluten-block- ing method is the specific blocking of toxic gluten fragments by microbial tissue-transglutaminase (Streptomyces mobaraensis) using lysine methyl ester. It has a great advantage because blocking the immunogenicity of T-cell epitopes does not damage the gluten network and preserves the technological properties of flour. Marino et al. [2017] assessed the safety of mTG-modified wheat flour for patients with CD and found that transamidated gluten reduced the number of clinical relapses to a limited extent. There would be a need for more extensive clinical trials to confirm the safety of enzymatic treatment of wheat flour for individuals with $\mathrm{CD}$, including further investigation involving a large number of volunteers who consumed products from detoxified wheat flour.

Wheat flour transamidation can be a good alternative to a GFD, but there is not enough scientific evidence that this method is $100 \%$ safe. Scientists are worried and warned against the transglutaminase added to the industrially-processed food, doubting its safety and bringing up its putative role in CD pathogenesis [Aaron \& Torsten, 2019]. There are ample studies that have shown that transglutaminase causes some neurodegenerative diseases, such as Alzheimer disease and Huntington disease [Amirdivani et al., 2018]. Furthermore, it is supposed that industrial processing of food using microbial transglutaminase to improve its properties has a negative effect on the gluten-sensitive population: it creates new immunogenic gluten peptides [Lerner \& Matthias, 2015; Matthias et al., 2016] and may affect autoantigen occurrence in patients with $\mathrm{CD}$.

\section{Enzymes of fungal origin}

Fungal proteases, commonly used as quality enhancers for baked goods, can cause primary proteolysis of gluten. Results of studies have shown that endoproteases from Aspergillus niger (AnP2), (AN-PEP) effectively degrade gluten proteins. Stepniak et al. [2006] noticed that Aspergillus niger (AnP2) prolyl endoprotease had optimal activity at $\mathrm{pH} 4-5$ and remained stable at $\mathrm{pH}$ 2. Furthermore, the A. niger-derived enzyme effectively degraded all the T-cell stimulants and non-degraded gluten molecules. On average, the AnP2 degraded gluten 60 times faster than prolyl oligopeptidases. Low doses of pure AN-PEP can effectively reduce the amount of gluten fragments [Janssen et al., 2015; Kumar Mohan et al., 2019]. Toft-Hansen et al. [2014] tested 25 proteases and investigated 10 of them for their potential to degrade gluten in vitro. They proved that the protease from Aspergillus niger (AnP2) completely degraded gluten. In turn, Socha et al. [2015] tested the proteolytic activity of fungal proteases isolated from Aspergillus sp., Aspergillus oryzae, and Aspergillus niger. The most effective proteolytic activity was also observed with the use of acid proteinase (AN-PEP) from A. niger, since wheat gliadins and peptides of low molecular weight were completely hydrolyzed. This prolyl endoprotease can also be used as an oral supplement to reduce the effect of gluten on consumers. AN-PEP can accelerate the digestion of gluten in the gastrointestinal tract [Salden et al., 2015]. This means that using AN-PEP in combination with gluten-containing food can eliminate the toxic effects of gluten, thus offering the possibility to refuse (occasionally) a strict GFD [Mitea et al., 2008; Montserrat et al., 2015]. Fungal proteases have the highest activity in 
degrading gluten immunotoxic compounds compared to other proteases [Socha et al., 2015]. The composition of food affects the amount of AN-PEP required to eliminate gluten [Montserrat et al., 2015]. Studies have shown that single fungi-derived proteases can be effective for gluten degradation and that the combination of several fungal proteases allows a faster reduction in the content of toxic gluten fragments using only one enzyme [Ehren et al., 2009]. The ability of Flavourzyme (an enzyme complex from Aspergillus oryzae) to hydrolyze the prolamins of wheat was investigated. The results showed that Flavourzyme effectively degraded gliadins and could significantly reduce their immunotoxicity [Mickowska et al., 2018]. Schultz et al. [2018] investigated the ability of prolyl endopeptidases extracted from Flammulina velutipes (FvpP) to hydrolyze gluten. The FvpP hydrolyzed $\alpha$-gliadin into small, less hydrophobic peptides after 20-h incubation. It was active at different $\mathrm{pH}$ values and higher salt concentrations, i.e., under similar conditions as in grain products, showed a moderate temperature stability, and slight thermal inactivation after use.

Studies have shown that fungi-derived proteases could be considered the most effective for gluten degradation. Further research should focus on using AN-PEP-treated starch in GF bakery products, and on degrading gluten in wheat bran or fermented food products to maintain a high nutritional value, and good technological and organoleptic properties, for example, in leavened products. However, doubts remain as to whether the use of these proteases is completely safe in the production of wheat products and acceptable to consumers.

\section{Enzymes of plant origin}

The use of plant enzymes is not a new concept in the baking industry. These enzymes play an important role in the production of some foods: syrups, alcoholic beverages, dairy products, bakery products, etc. [Meshram et al., 2019]. Plant proteases are enzymes that are commonly found in fruits, such as papaya, pineapples, figs, and kiwifruit. Sun et al. [2016] evaluated protease activity in 90 species of plants, including fruit and vegetables. Ten types of fruit and thirteen vegetables possessed high protease activity. Pineapples, figs, and papaya used to produce commercial proteases showed a high level of protease activity. In addition, high protease activity was detected in kiwifruit, broccoli, ginger, leek, and red pepper. Based on data above, it can be concluded that plants have high untapped potential as candidates for plant protease production.

Papain, bromelain, and actinidin belong to the cysteine protease family and exhibit a high hydrolytic potential. Papain was used to produce wheat gluten hydrolysates, a by-product of wheat starch production. During treatment with papain, the low molecular weight peptides were released from proteins [Wang et al., 2007]. Papain destroyed allergenic epitopes by hydrolyzing gliadins into small peptides [Buddrick et al., 2015; Xue et al., 2019] and exhibited great effects on gliadin hydrolysis even at its very low concentration [Li et al., 2016]. Bromelain was used to produce hypoallergenic flour suitable for patients with wheat allergies. It can hydrolyze peptide bonds in proline residues and thereby alter the structure of gluten fragments [Watanabe et al., 2000].
Kiwifruit proteases are enzymes belonging to the cysteine protease family of papain. An in vitro study [Kaur et al., 2010] showed that actinidine from a green kiwifruit affected protein digestion in the small intestine. Various food proteins, including cereal gluten, have been incubated with or without green kiwifruit extract using a two-stage in vitro digestive system consisting of an incubation with pepsin at stomach $\mathrm{pH}$ (mimicking gastric digestion) and then with pancreatin at low intestinal $\mathrm{pH}$, imitating the human digestive tract. The kiwifruit extract affected gluten absorption. Actinidin has been shown to improve gluten digestion in experimental rats [Rutherfurd et al., 2011]. Jayawardana et al. [2019] analyzed the possibility of minimizing gluten intolerance by co-consumption of some fruits: papaya, pineapple and green kiwifruit, and highlighted the potential of green kiwifruit for consumption as a means of minimizing adverse effects of dietary gluten.

As Taga et al. [2017] proved, ginger protease can also hydrolyze gluten to peptides with an average molecular weight of $<600$ Da under weak acidic conditions. Data obtained from the studies performed by Bellir et al. [2014] and Gabr [2018] have confirmed that Nigella sativa (also known as blackseed or black caraway) had proteases that could be used in the food industry. The protease from the seeds of $N$. sativa can hydrolyze the gluten protein; therefore, it can be used to treat coeliac disease. $N$. sativa seed proteases, due to their ability to detoxify gluten, may offer an alternative treatment for $\mathrm{CD}$ in the future. Less common plants also have active proteolytic enzymes. Considerable attention was drawn to the study of digestive enzymes of an exotic fleshy plant Nepenthes pitcher, including protease nepenthesin [Ravee et al., 2018]. The Nepenthes pitcher fluid has a particularly strong ability to detoxify gluten, which can be associated with the formation of a new generation of prolyl endoproteases [Rey et al., 2016; Schräder et al., 2017]. Cumin (Cuminum cyminum L.) water extracts have high protease activity too. Cumin seed peptides significantly increased the proteolytic activity of pepsin (up to 400\%) [Siow et al., 2016]; however experiments with gluten have not been performed.

\section{Enzymes of animal origin and human digestive enzymes}

Wheat gluten can be hydrolyzed using various enzymes of animal origin. A number of studies have been published in which wheat gluten has been degraded by commercial proteases of animal origin (pepsin, pancreatin, trypsin and chymotrypsin). All enzymes cleaved gliadin to peptides with a lower molecular weight (10-15 kDa), and chymotrypsin was the most effective; however, their effects have been found to be limited [Cao et al., 2020; Giorgi et al., 2020].

Insects and larvae have many strong proteolytic enzymes in the digestive tract [Grover et al., 2018; Pilon et al., 2017]. Insect enzymes have been shown to be specially adapted for the efficient hydrolysis of wheat proteins. A proline specific serine peptidase from the midgut of the yellow mealworm (Tenebrio molitor) can actively hydrolyze wheat gluten to polypeptides [Tereshchenkova et al., 2016]. Proteolytic bacteria from the gut of the velvetbean caterpillar (Anticarsia gemmatalis) showed increased activity at $40^{\circ} \mathrm{C}$, and were active at pH 7.5-10 [Pilon et al., 2017]. From among all the tested insects, Rhizopertha dominica showed the highest activity of 
prolyl peptidase [Mika et al., 2015]. The proteolytic activity in $R$. dominica is owed to the trypsin-type enzymatic activity. This enzyme has been cloned and characterized but has not been used in the gluten-free food industry. Gutierrez et al. [2017] showed that enzymes of the gastrointestinal elastase 3B, elastase $2 \mathrm{~A}$, and carboxypeptidase $\mathrm{A} 1$ from human digestive tract could also degrade gluten. The investigation of the ability to degrade typical gluten peptides showed that, although they all were cleaved by proteases to a certain extent, the proteolysis products remained immunoreactive to coeliac T-cells and were likely to induce signs of CD [Tavano et al., 2018].

\section{COMBINED APPROACH FOR WHEAT GLUTEN ALLERGENICITY ABOLISHMENT}

Even if the enzyme treatment alone is unable to fully eliminate the immunogenicity of wheat products, the combined approach would allow applying these products in GF diet. There are various options for combining different methods. The results of studies on the combination of several biological treatments to eliminate the immunogenicity of wheat are presented in Table 3.

\section{Combination of cereal germination with LAB fermentation}

As reported by Loponen et al. [2007] and Montemurro et al. [2019], almost all wheat prolamins (gliadins and glutenins) were degraded during sourdough fermentation of sprouted wheat flour. Prolamin hydrolysis in sourdough of germinated wheat was more intense, possibly due to the high activity of cysteine proteinase in germinated wheat. Both of these methods are natural, and products made in this way are likely to be attractive to consumers, but they are not $100 \%$ effective.

\section{Combination of cereal germination with fungal proteases treatment}

Fungal proteases are often used to produce GF beer [Guerdrum \& Bamforth, 2012]. Malt hydrolysis with AN-PEP resulted in a significant reduction in the residual prolamin content. There are previous studies [Walter et al., 2014] that fungal proteases successfully hydrolyzed gluten residues in sprouted wheat bran, but there have been no recent studies in this area.

\section{Combination of selected Lactobacillus cultures with different proteases treatment}

It has been shown that using selected LAB together with different proteases over a long time can reduce the residual content of gluten immunogenic sequences. The required fermentation time for gluten degradation was significantly reduced (up to $12-20 \mathrm{~h}$ at $30-37^{\circ} \mathrm{C}$ ) using fungal proteases [Giuliani et al., 2016]. This effect was obtained using only two selected lactic acid bacteria (L. sanfranciscensis DPPMA12 and $L$. plantarum DPPMA125) in combination with fungal proteases (isolated from Aspergillus oryzae, A. niger, or mixtures thereof). It has been found that LAB and fungal proteases can degrade the gluten of different wheat varieties, and the good tolerance to such treated wheat in coeliac patients has been demonstrated.
Curiel et al. [2014] have developed a technology for producing gluten-free pasta using entirely hydrolyzed wheat flour with good organoleptic characteristics and nutritional value. Wheat flour fermentation with LAB and fungal proteases reduces the content of gluten. The study by Arte et al. [2015] revealed the effects of various biological treatment methods, such as activation of endogenous bran enzymes, addition of an enzyme mixture, and microbial fermentation on wheat bran protein modification. The biological treatment in acidic media significantly increased the solubility of wheat bran protein. The study by Di Cagno et al. [2010] has shown that young coeliac patients are safe to eat sweet pastries made from wheat flours that have become GF during the fermentation. After fermentation, the wheat flour was dried in a spray dryer and used to produce sweet pastries. Selected LAB cultures and fungal proteases, commonly used for bakery products, degraded gluten to $<10 \mathrm{mg} / \mathrm{kg}$. Greco et al. [2011] have also proved that there is no immune response in $\mathrm{CD}$ patients who daily consume baked goods produced from hydrolyzed wheat flour. The tolerance to such treated wheat in coeliac patients has been proven on short-term consumption [Mandile et al., 2017]. This patented method encourages the already applied practice in Italy to produce GF bakery products with sourdough and pasta. However, more detailed clinical surveys are needed to demonstrate its long-term safety as well the technological properties of wheat flours with hydrolyzed gluten, and to elucidate its impact on the baking process. Whether the broken gluten network is replaced by hydrocolloids, the question arises - whether it is expedient to use such flour after gluten hydrolysis for baking, or might it be better to use wheat starch for bread making.

\section{Combination of enzymes of different origins}

Studies have shown that concomitant use of several enzymes leads to more efficient degradation of gluten than the use of individual enzymes. The use of several different enzymes together (of plant, bacterial, animal, or fungal origin), that cleave different peptide bonds has improved the efficiency of gluten hydrolysis [Brzozowski et al., 2020; Janssen et al., 2015]. Li et al. [2016] found that the sequential hydrolysis of wheat flour using several different enzymes was more effective in reducing the amount of gliadin than the hydrolysis by every individual enzyme. The sequential fermentation of wheat flour with Alcalase and papain almost completely eliminated the gluten under optimal conditions. It is obvious that, under suitable conditions, such hydrolysis is a promising way of producing low-allergenic wheat products. However, the organoleptic and functional characteristics of the Alcalase-papain-treated product have to be examined to determine the feasibility of this method for production. Although wheat gluten can be hydrolyzed using enzymes of different origins, it is necessary to carefully select them and manage the hydrolysis process to achieve the desired effect, since improper organization of the process can have the opposite effect [Tavano et al., 2018]. Therefore, some GF food additives can have a negative effect on consumers associated with wheat intolerance and even on patients with coeliac disease. The manufacturing process of GF products should be carefully designed and managed to avoid complications. It remains the challenge to 
TABLE 3. Combined approach of several biological treatments to eliminate the immunogenicity of wheat.

\begin{tabular}{|c|c|c|c|}
\hline Combined treatment & Enzyme source & Results & References \\
\hline $\begin{array}{l}\text { Malting or germinating } \\
+ \text { sourdough } \\
\text { fermentation }\end{array}$ & $\begin{array}{l}\text { Lactobacillus rossiae, L.plantarum and } \\
\text { L. sanfranciscensis were used for fermentation } \\
\text { of flours from germinated grains }\end{array}$ & $\begin{array}{l}\text { Fermentation enhanced the nutritional and } \\
\text { functional features of sprouted flours. }\end{array}$ & Montemurro et al. [2019] \\
\hline $\begin{array}{l}\text { Malting or germinating } \\
+ \text { fungal proteases }\end{array}$ & $\begin{array}{c}\text { Bran extracts from germinated cereals }+ \\
\text { Aspergillus niger prolyl endopeptidase } \\
\end{array}$ & $\begin{array}{l}\text { AN-PEP exceeded the activities of } \\
\text { germinated cereal in gluten degradation. }\end{array}$ & Walter et al. [2014] \\
\hline \multirow{2}{*}{$\begin{array}{l}\text { Sourdough } \\
\text { fermentation+ } \\
\text { fungal proteases }\end{array}$} & $\begin{array}{l}\text { L. sanfranciscensis and } L . \text { plantarum } \\
\text { in combination with fungal proteases } \\
\text { from A. oryzae and A. niger }\end{array}$ & $\begin{array}{l}\text { The required fermentation time for gluten } \\
\text { degradation significantly reduced. }\end{array}$ & Giuliani et al. [2016] \\
\hline & $\begin{array}{l}\text { White bread was prepared from } \\
\text { wheat flour pre-treated with selected } \\
\text { lactobacilli and fungal proteases }\end{array}$ & $\begin{array}{l}\text { Such bread did not affect an immune } \\
\text { response in patients with CD on } \\
\text { short-term consumption. }\end{array}$ & Mandile et al. [2017] \\
\hline $\begin{array}{l}\text { Sourdough } \\
\text { fermentation }+ \\
\text { proteases of } \\
\text { animal origin }\end{array}$ & $\begin{array}{l}\text { Mixture of } 5 \text { different bacterial } \\
\text { strains by a combination of pepsin, } \\
\text { trypsin or chymotrypsin }\end{array}$ & $\begin{array}{l}\text { Probiotic strains reduced the } \\
\text { toxicity of gliadin that remains } \\
\text { after peptic-tryptic digestion. }\end{array}$ & Giorgi et al. [2020] \\
\hline \multirow{4}{*}{$\begin{array}{l}\text { Enzymes of } \\
\text { different origin }\end{array}$} & $\begin{array}{l}\text { Activation of endogenous wheat bran } \\
\text { enzymes in addition of microbial fermentation }\end{array}$ & $\begin{array}{l}\text { Biological treatment significantly increased } \\
\text { solubility of wheat bran proteins. }\end{array}$ & Arte et al. [2015] \\
\hline & $\begin{array}{c}\text { Pepsin and other digestive } \\
\text { supplements+ AN-PEP enzyme }\end{array}$ & $\begin{array}{l}\text { AN-PEP enzyme enhanced the } \\
\text { effects of digestive supplements. }\end{array}$ & Janssen et al. [2015] \\
\hline & $\begin{array}{l}\text { Chymotrypsin, Flavourzyme, Trypsin, } \\
\text { Pepsin or Alcalase + Papain }\end{array}$ & $\begin{array}{l}\text { Alcalase-papain significantly reduced } \\
\text { allergenicity of wheat flour. }\end{array}$ & Li et al. [2016] \\
\hline & $\begin{array}{l}\text { The mixture of peptidases from } \\
\text { L. acidophilus }+ \text { A. niger }\end{array}$ & $\begin{array}{c}\text { Coeliac-toxic peptides were } \\
\text { hydrolyzed effectively after } 3 \mathrm{~h} \text {. }\end{array}$ & Brzozowski et al. [2020] \\
\hline
\end{tabular}

manage process factors such as enzyme type and its activity, content of proteins, $\mathrm{pH}$, action mechanism, reaction time, and others. These conditions do not always correspond to the real conditions of wheat products manufacture in practice. Besides, additional measures are necessary to compensate for the reduction or elimination of gluten in order to ensure high product quality.

\section{Combined approach of biotechnological and non- -biotechnological measures}

A number of studies have been performed to degrade gluten-immunotoxic compounds by physical treatments. Lamacchia et al. [2016] studied the effects of microwaves on soaked wheat kernels and reported that this modification could reduce the immunotoxic effects of wheat proteins by up to $99 \%$, which would allow them to produce low-gluten bread. However, subsequent studies [Gianfrani et al., 2017] had used more accurate methods for the determination of gluten residues and observed that the microwave treatment did not reduce the celiac immunogenicity of gliadins. As Mahroug et al. [2019] confirmed, despite the significant changes observed in the gluten secondary structure, the microwave treatment was ineffective in decreasing the amount of potential celiac-toxic epitopes in wheat flour but even increased it when the flour was exposed to the low doses of energy [Leszczynska et al., 2003]. The reduction of the residual antigenicity of wheat proteins can be achieved during thermal treatment, by using high pressure, extrusion, and spray drying [Stănciuc et al., 2018]; however, the effect was not sufficient to make wheat products suitable for gluten-sensitive people.

Another physical method - ultrasound treatment, can significantly improve emulsifying, foaming, and rheological properties of wheat gluten proteins, but slightly decreases their molecular weight [Zhang et al., 2011]. The ultrasound effects on the immunogenicity of wheat gluten are insignificant, but it can be used to activate enzymatic hydrolysis. Controlled ultrasound pretreatment can alter the microstructure, nano-mechanical properties, and secondary structures of wheat gluten, to increase the content of free amino acids and to improve the effects of enzymolysis [Zhang et al., 2015; Yang et al., 2017]. Combined enzyme/ultrasound bioprocessing produces cavitation effects that enhance the transport of enzyme macromolecules to the surface of the substrate and thus activates the action of enzymes [Delgado-Povedano \& De Castrož, 2015; Kwiatkowska et al., 2011]. However, time and power control is very important in this process, because choosing the wrong cavitation parameters can reduce the degree of enzymatic hydrolysis [Islam et al., 2014; Yu et al., 2014].

Thus, although physical methods would be more accessible and do not require much energy and time, the enzymatic hydrolysis appears to be a more effective approach in minimizing allergenicity of wheat proteins [Rahaman et al., 2016]. However, the possibility of combining physical and biotechnological measures should be further explored.

\section{CONCLUSIONS}

The current gluten-free products available on the market have technological and sensory drawbacks. Due to the growing trend of gluten-free market in the last years, technologies for the production of gluten-free or reduced-gluten wheat products are being developed. Research on the use of the biological approach in wheat products in order to eliminate or reduce the immune toxicity of gluten proteins is being actively undertaken. Various enzymes, such as those of bacte- 
rial, fungal, plant and animal origin, can be used to this end. Most of the studies were carried out using cultures of lactic acid, inlcuding their individual strains or various combinations. Selected strains that exhibit proteolytic activity, which reduces the allergenicity of wheat sourdough, can be used as specific starter LAB cultures to prepare foods for special purposes. Satisfactory results are achieved by using bacterial and plant enzymes, but the complete elimination of gluten immunogenicity in wheat products is still possible only by using fungal proteases, engineered enzymes or combining several treatments, for example, by using LAB fermentation or germination with fungal proteases. Despite numerous research in scientific laboratories, it is still impossible to offer patients with $\mathrm{CD}$ an alternative diet based on highly nutritious and tasty cereal GF products in practice.

The applicability of the used techniques in bread and bakery production is uncertain. Complete degradation of gluten requires long fermentation times, often in combination of several strains of different lactic acid bacteria. Moreover, with the addition of peptidases, gluten degradation must be controlled. This long and complicated process also leads to higher production costs of the final product. Furthermore, when wheat gluten is completely degraded, the viscoelastic properties are lost, which reduces the benefits of the process [Engström et al., 2015]. Without the use of additives, the optimal dough and cereal product cannot be prepared from such altered and processed wheat grains or flours. The safety of such products has not been fully proven. It has not been established whether the products of such wheat flour are better than those made from starches and whether their price and quality are acceptable to consumers. Furthermore, the question remains unanswered: Is it beneficial to degrade gluten in wheat flours?

As the majority of the studied biotechnological tools readily remove small amounts of gluten, it would be appropriate to use wheat by-products after physical removal of gluten by wet fractionation. However, further research should focus on using enzymatically-treated wheat starch and bran in gluten-free bakery products or fermented food products with a high nutritional value, and good technological and organoleptic properties, that can be consumed not only by people suffering from gluten intolerance, but also by other personalized groups of consumers.

\section{RESEARCH FUNDING}

This research did not receive any specific grant from funding agencies in the public, commercial, or not-for-profit sectors.

\section{CONFLICT OF INTERESTS}

Authors declare no conflict of interest.

\section{ORCID IDs}

V. Bradauskiene https://orcid.org/0000-0003-1869-0807 D. Cernauskas https://orcid.org/0000-0002-7094-0183 L. Vaiciulyte-Funk https://orcid.org/0000-0002-2865-9523

\section{REFERENCES}

1. Aaron, L., Torsten, M. (2019). Microbial transglutaminase: A new potential player in celiac disease. Clinical Immunology, 199, 37-43. https://doi.org/10.1016/j.clim.2018.12.008

2. Adrianos, S.L., Mattioni, B., Tilley, M. (2017). Confirmation of gluten-free status of wheatgrass (Triticum aestivum). Quality Assurance and Safety of Crops \& Foods, 9(1), 123-128. https://doi.org/10.3920/QAS2015.0764

3. Alvarez-Sieiro, P., Martin, M.C., Redruello, B., Del Rio, B., Ladero, V., Palanski, B.A., Khosla, C., Fernandez, M., Alvarez, M.A. (2014). Generation of food-grade recombinant Lactobacillus casei delivering Myxococcus xanthus prolyl endopeptidase. Applied Microbiology and Biotechnology, 98(15), 6689-6700. https://doi.org/10.1007/s00253-014-5730-7

4. Amirdivani, S., Khorshidian, N., Fidelis, M., Granato, D., Koushki, M.R., Mohammadi, M., Khoshtinat, K., Mortazavian, A.M. (2018). Effects of transglutaminase on health properties of food products. Current Opinion in Food Science, 22, 74-80. https://doi.org/10.1016/j.cofs.2018.01.008

5. Arte, E., Rizzello, C.G., Verni, M., Nordlund, E., Katina, K., Coda, R. (2015). Impact of enzymatic and microbial bioprocessing on protein modification and nutritional properties of wheat bran. Journal of Agricultural and Food Chemistry, 63(39), 8685-8693.

https://doi.org/10.1021/acs.jafc.5b03495

6. Baranzelli, J., Kringel, D.H., Colussi, R., Paiva, F.F., Aranha, B.C., de Miranda, M.Z., Zavareze, E. da R., Dias, A.R.G. (2018). Changes in enzymatic activity, technological quality and gammaaminobutyric acid (GABA) content of wheat flour as affected by germination. LWT - Food Science and Technology, 90, 483-490. https://doi.org/10.1016/j.Iwt.2017.12.070

7. Bassi, N.D. (2016). Gluten-free starch and methods of producing the same. U.S. Patent Application No. 15/193, 622.

8. Bellir, N., Bellir, M.N., Rouabah, L. (2014). Enzymatic degradation of gliadin by Nigella sativa seeds protease: Implications for new treatment of celiac disease. World Journal of Pharmacy Sciences, 3(12), 1555-1571.

9. Boukid, F., Mejri, M., Pellegrini, N., Sforza, S., Prandi, B. (2017a). How looking for celiac-safe wheat can influence its technological properties. Comprehensive Reviews in Food Science and Food Safety, 16(5), 797-807.

https://doi.org/10.1111/1541-4337.12288

10. Boukid, F., Prandi, B., Buhler, S., Sforza, S. (2017b). Effectiveness of germination on protein hydrolysis as a way to reduce adverse reactions to wheat. Journal of Agricultural and Food Chemistry, 65(45), 9854-9860.

https://doi.org/10.1021/acs.jafc.7b03175

11. Bromilow, S., Gethings, L.A., Buckley, M., Bromley, M., Shewry, P.R., Langridge, J.I., Mills, E.C. (2017). A curated gluten protein sequence database to support development of proteomics methods for determination of gluten in gluten-free foods. Journal of Proteomics, 163, 67-75.

https://doi.org/10.1016/j.jprot.2017.03.026

12. Bruins Slot, I.D., Bremer, M.G.E.G., Hamer, R.J., van der Fels-Klerx, H.J. (2015). Part of celiac population still at risk despite current gluten thresholds. Trends in Food Science \& Technology, 43(2), 219-226.

https://doi.org/10.1016/j.tifs.2015.02.011 
13. Brzozowski, B., Stasiewicz, K., Ostolski, M., Adamczak, M. (2020). Reducing immunoreactivity of gliadins and coeliac-toxic peptides using peptidases from L. acidophilus $5 e 2$ and A. niger. Catalysts, 10(8), art no. 923.

https://doi.org/10.3390/catal10080923

14. Buddrick, O., Cornell, H.J., Small, D.M. (2015). Reduction of toxic gliadin content of wholegrain bread by the enzyme caricain. Food Chemistry, 170, 343-347.

https://doi.org/10.1016/j.foodchem.2014.08.030

15. Cao, W., Baumert, J.L., Downs, M.L. (2020). Evaluation of $\mathrm{N}$-terminal labeling mass spectrometry for characterization of partially hydrolyzed gluten proteins. Journal of Proteomics, 210, art. no. 103538 .

https://doi.org/10.1016/j.jprot.2019.103538

16. Cardone, G., D’Incecco, P., Pagani, M.A., Marti, A. (2020). Sprouting improves the bread-making performance of whole wheat flour (Triticum aestivum L.). Journal of the Science of Food and Agriculture, 100(6), 2453-2459.

https://doi.org/10.1002/jsfa.10264

17. Catassi, C., Elli, L., Bonaz, B., Bouma, G., Carroccio, A., Castillejo, G., Cellier, C., Cristofori, F., de Magistris, L., Dolinsek, J., Dieterich, W., Francavilla, R., Hadjivassiliou, M., Holtmeier, W., Körner, U., Leffler, D.A., Lundin, K.E.A., Mazzarella, G., Mulder, C.J., Fasano, A. (2015). Diagnosis of non-celiac gluten sensitivity (NCGS): the Salerno experts' criteria. Nutrients, 7(6), 4966-4977. https://doi.org/10.3390/nu7064966

18. Cavaletti, L., Taravella, A., Carrano, L., Carenzi, G., Sigurtà, A., Solinas, N., De Caro, S., Di Stasio, L., Picascia, S., Laezza, M., Troncone, R., Gianfrani, C., Mamone, G. (2019). E40, a novel microbial protease efficiently detoxifying gluten proteins, for the dietary management of gluten intolerance. Scientific Reports, 9(1), art. no. 13147.

https://doi.org/10.1038/s41598-019-48299-7

19. Chishty, S., Singh, N. (2017). Nutritional status of celiac and non-celiac children from Rajasthan, India. Nutrition \& Food Science, 47(2), 240-253.

https://doi.org/10.1108/NFS-05-2016-0056

20. Cruz-Chamorro, I., Álvarez-Sánchez, N., Santos-Sánchez, G., Pedroche, J., Fernández-Pachón, M.S., Millán, F., Millán-Linares, M.C., Lardone, P.J., Bejarano, I., Guerrero, J.M., Carrillo-Vico, A. (2020). Immunomodulatory and antioxidant properties of wheat gluten protein hydrolysates in human peripheral blood mononuclear cells. Nutrients, 12(6), art no. 1673.

https://doi.org/10.3390/nu12061673

21. Curiel, J.A., Coda, R., Limitone, A., Katina, K., Raulio, M., Giuliani, G., Rizzello, C.G., Gobbetti, M. (2014). Manufacture and characterization of pasta made with wheat flour rendered gluten-free using fungal proteases and selected sourdough lactic acid bacteria. Journal of Cereal Science, 59(1), 79-87. https://doi.org/10.1016/j.jcs.2013.09.011

22. De Almeida, N.E.C., Esteves, F.G., dos Santos-Pinto, J.R.A., Peres De Paula, C., Da Cunha, A.F., Malavazi, I., Palma, M.S., Rodrigues-Filho, E. (2020). Digestion of intact dluten proteins by bifidobacterium species: reduction of cytotoxicity and proinflammatory responses. Journal of Agricultural and Food Chemistry, 68(15), 4485-4492.

https://doi.org/10.1021/acs.jafc.0c01421
23. De Angelis, M., Rizzello, C.G., Fasano, A., Clemente, M.G., De Simone, C., Silano, M., De Vincenzi, M., Losito, I., Gobbetti, M. (2006). VSL\# 3 probiotic preparation has the capacity to hydrolyze gliadin polypeptides responsible for celiac sprue probiotics and gluten intolerance. Biochimica et Biophysica Acta (BBA) Molecular Basis of Disease, 1762(1), 80-93.

https://doi.org/10.1016/j.bbadis.2005.09.008

24. Delgado-Povedano, M.M., De Castro, M.L. (2015). A review on enzyme and ultrasound: A controversial but fruitful relationship. Analytica Chimica Acta, 889, 1-21. https://doi.org/10.1016/j.aca.2015.05.004

25. Diaz-Mendoza, M., Diaz, I., Martinez, M. (2019). Insights on the proteases involved in barley and wheat grain germination. International Journal of Molecular Sciences, 20(9), 2087-2098. https://doi.org/10.3390/ijms20092087

26. Di Cagno, R., Barbato, M., Di Camillo, C., Rizzello, C.G., De Angelis, M., Giuliani G., De Vincenzi, M., Gobbetti, M., Cucchiara, S. (2010). Gluten-free sourdough wheat baked goods appear safe for young celiac patients: a pilot study. Journal of Pediatric Gastroenterology and Nutrition, 51 (6), 777-783. https://doi.org/10.1097/MPG.0b013e3181f22ba4

27. Di Cagno, R., De Angelis, M., Auricchio, S., Greco, L., Clarke, C., De Vincenzi, M., Giovannini, C., D'Archivio, M., Landolfo, F., Parrilli, G., Minervini, F., Arendt, E., Gobbetti, M. (2004). Sourdough bread made from wheat and nontoxic flours and started with selected Lactobacilli is tolerated in celiac sprue patients. Applied and Environmental Microbiology, 70, 1088-1096. https://doi.org/10.1128/AEM.70.2.1088-1096.2004

28. Di Cagno, R., De Angelis, M., Lavermicocca, P., De Vincenzi, M., Giovannini, C., Faccia, M., Gobbetti, M. (2002). Proteolysis by sourdough lactic acid bacteria: effects on wheat flour protein fractions and gliadin peptides involved in human cereal intolerance. Applied and Environmental Microbiology, 68(2), 623-633. https://doi.org/10.1128/AEM.68.2.623-633.2002

29. Di Cagno, R., Rizzello, C.G., De Angelis, M., Cassone, A., Giuliani, G., Benedusi, A., Limitone, A., Surico, R.F., Gobbetti, M. (2008). Use of selected sourdough strains of Lactobacillus for removing gluten and enhancing the nutritional properties of gluten-free bread. Journal of Food Protection, 71 (7), 1491-1495. https://doi.org/10.4315/0362-028X-71.7.1491

30. Ding, J., Hou, G.G., Nemzer, B.V., Xiong, S., Dubat, A., Feng, H. (2018). Effects of controlled germination on selected physicochemical and functional properties of whole-wheat flour and enhanced $\gamma$-aminobutyric acid accumulation by ultrasonication. Food Chemistry, 243, 214-221.

https://doi.org/10.1016/j.foodchem.2017.09.128

31. Do Nascimento, A.B., Fiates, G.M.R., Teixeira, E. (2017). We want to be normal! Perceptions of a group of Brazilian consumers with coeliac disease on gluten-free bread buns. International Journal of Gastronomy and Food Science, 7, 27-31. https://doi.org/10.1016/j.ijgfs.2017.01.001

32. Ehren, J., Morón, B., Martin, E., Bethune, M.T., Gray, G.M., Khosla, C. (2009). A food-grade enzyme preparation with modest gluten detoxification properties. PloS ONE, 4(7), art. no. e6313. https://doi.org/10.1371/journal. pone.0006313

33. El-Ghaish, S., Ahmadova, A., Hadji-Sfaxi, I., El Mecherfi, K.E., Bazukyan, I., Choiset, Y., Rabesona, H., Sitohy, M., Popov, Y.G., Kuliev, A.A., Mozzi, F., Chobert, J.M., Haertlé, T. (2011). Potential use of lactic acid bacteria for reduction of allergenicity 
and for longer conservation of fermented foods. Trends in Food Science \& Technology, 22(9), 509-516.

https://doi.org/10.1016/j.tifs.2011.05.003

34. Engström, N., Sandberg, A.S., Scheers, N. (2015). Sourdough fermentation of wheat flour does not prevent the interaction of transglutaminase 2 with $\alpha 2$-gliadin or gluten. Nutrients, 7(4), 2134-2144.

https://doi.org/10.3390/nu7042134

35. Estévez, V., Ayala, J., Vespa, C., Araya, M. (2016). The gluten-free basic food basket: a problem of availability, cost and nutritional composition. European Journal of Clinical Nutrition, 70(10), 1215-1217.

https://doi.org/10.1038/ejcn.2016.139

36. FAOSTAT, [dataset] Production/Yield quantities of Wheat in World + (Total). (2020). Food and Agriculture Organization [http://faostat.fao.org/site/291/default.aspx].

37. Francavilla, R., De Angelis, M., Rizzello, C.G., Cavallo, N., Dal Bello, F., Gobbetti, M. (2017). Selected probiotic lactobacilli have the capacity to hydrolyze gluten peptides during simulated gastrointestinal digestion. Applied and Environmental Microbiology, 83(14), art no. e0036-37. https://doi.org/10.1128/AEM.00376-17

38. Fu, W., Xue, W., Liu, C., Tian, Y., Zhang, K., Zhu, Z. (2020). Screening of Lactic Acid Bacteria and yeasts from sourdough as starter cultures for reduced allergenicity wheat products. Foods, 9(6), 751-761. https://doi.org/10.3390/foods9060751

39. Gabr, G.A. (2018). Extraction and purification of protease from Nigella sativa for its potential use in celiac disease. Asian Journal of Biotechnology and Bioresource Technology, 8(3), 1-9. https://doi.org/10.9734/AJB2T/2018/44555

40. Gänzle, M.G., Loponen, J., Gobbetti, M. (2008). Proteolysis in sourdough fermentations: mechanisms and potential for improved bread quality. Trends in Food Science \& Technology, 19(10), 513-521.

https://doi.org/10.1016/j.tifs.2008.04.002

41. Gerez, C.L., Dallagnol, A., Rollán, G., de Valdez, G.F. (2012) A combination of two lactic acid bacteria improves the hydrolysis of gliadin during wheat dough fermentation. Food Microbiology, 32(2), 427-430. https://doi.org/10.1016/j.fm.2012.06.007

42. Gerez, C.L., Font de Valdez, G., Rollan, G.C. (2008). Functionality of lactic acid bacteria peptidase activities in the hydrolysis of gliadin-like fragments. Letters in Applied Microbiology, 47(5), 427-432. https://doi.org/10.1111/j.1472-765X.2008.02448.x

43. Geßendorfer, B., Hartmann, G., Wieser, H., Koehler, P. (2011). Determination of celiac disease-specific peptidase activity of germinated cereals. European Food Research and Technology, 232(2), 205-209.

\section{https://doi.org/10.1007/s00217-010-1375-7}

44. Gianfrani, C., Mamone, G., La Gatta, B., Camarca, A., Di Stasio, L., Maurano, F., Picascia, S., Capozzi, V., Perna, G., Picariello, G., Di Luccia, A. (2017). Microwave-based treatments of wheat kernels do not abolish gluten epitopes implicated in celiac disease. Food and Chemical Toxicology, 101, 105-113. https://doi.org/10.1016/j.fct.2017.01.010

45. Giménez, M.J., Sánchez-León, S., Barro, F., García-Molina, M.D. (2019). Gluten free wheat: Are we there? Nutrients, II(3), art no. 487.

https://doi.org/10.3390/nu11030487
46. Giuliani, G., Benedusi, A., Di Cagno, R., Rizzello, C.G., De Angelis, M., Gobbetti, M., Cassone, A. (2016). Process of microbic biotechnology for completely degrading gluten in flours. U.S. Patent No. 9,386,777. Washington, U.S.A.

47. Giorgi, A., Cerrone, R., Capobianco, D., Filardo, S., Mancini, P., Fanelli, S., Mastromarino, P., Mosca, L. (2020). A probiotic preparation hydrolyzes gliadin and protects intestinal cells from the toxicity of pro-inflammatory peptides. Nutrients, 12 (2), 495, 1-13. https://doi.org/10.3390/nu12020495

48. Gobbetti, M., De Angelis, M., Di Cagno, R., Calasso, M., Archetti, G., Rizzello, C.G. (2019). Novel insights on the function$\mathrm{al} /$ nutritional features of the sourdough fermentation. International Journal of Food Microbiology, 302, 103-113.

https://doi.org/10.1016/j.ijfoodmicro.2018.05.018

49. Gordon, S.R., Stanley, E.J., Wolf, S., Toland, A., Wu, S.J., Hadidi, D., Siegel, J.B. (2012). Computational design of an $\alpha$-gliadin peptidase. Journal of the American Chemical Society, 134(50), 20513-20520.

https://doi.org/10.1021/ja3094795

50. Greco, L., Gobbetti, M., Auricchio, R., Di Mase, R., Landolfo, F., Paparo, F., Di Cagno, R., De Angelis, M., Rizzello, C.G., Cassone, A., Terrone, G., Timpone, L., D’Aniello, M., Maglio, M., Troncone, R., Auricchio, S. (2011). Safety for patients with celiac disease of baked goods made of wheat flour hydrolyzed during food processing. Clinical Gastroenterology and Hepatology, 9(1), 24-29. https://doi.org/10.1016/j.cgh.2010.09.025

51. Grover, S., Kaur, S., Gupta, A.K., Taggar, G.K., Kaur, J. (2018). Characterization of trypsin like protease from Helicoverpa armigera (Hubner) and its potential inhibitors. Proceedings of the National Academy of Sciences, India Section B: Biological Sciences, 88(1), 49-56.

https://doi.org/10.1007/s40011-016-0732-0

52. Guerdrum, L.J., Bamforth, C.W. (2012). Prolamin levels through brewing and the impact of prolyl endoproteinase. Journal of the American Society of Brewing Chemists, 70(1), 35-38.

https://doi.org/10.1094/ASBCJ-2012-0130-01

53. Gutiérrez, S., Pérez-Andrés, J., Martínez-Blanco, H., Ferrero, M.A., Vaquero, L., Vivas, S., Casqueiro, J., Rodríguez-Aparicio, L.B. (2017). The human digestive tract has proteases capable of gluten hydrolysis. Molecular Metabolism, 6(7), 693-702.

https://doi.org/10.1016/j.molmet.2017.05.008

54. Hartmann, G., Koehler, P., Wieser, H. (2006). Rapid degradation of gliadin peptides toxic for coeliac disease patients by proteases from germinating cereals. Journal of Cereal Science, 44(3), 368-371.

https://doi.org/10.1016/j.jcs.2006.10.002

55. Heredia-Sandoval, N.G., Valencia-Tapia, M.Y., Calderón de la Barca, A.M., Islas-Rubio, A.R. (2016). Microbial proteases in baked goods: modification of gluten and effects on immunogenicity and product quality. Foods, 5(3), art no. 59.

https://doi.org/10.3390/foods5030059

56. Hopkins, S., Soon, J.M. (2019). Nutritional quality, cost and availability of gluten-free food in England. British Food Journal, 121(11), 2867-2882. https://doi.org/10.1108/BFJ-09-2018-0607

57. Islam, M.N., Zhang, M., Adhikari, B. (2014). The inactivation of enzymes by ultrasound - a review of potential mechanisms. Food Reviews International, 30(1), 1-21.

https://doi.org/10.1080/87559129.2013.853772 
58. Janssen, G., Christis, C., Kooy-Winkelaar, Y., Edens, L., Smith, D., van Veelen, P., Koning, F. (2015). Ineffective degradation of immunogenic gluten epitopes by currently available digestive enzyme supplements. PLoS ONE, 10(6), art. no. e0128065.

https://doi.org/10.1371/journal.pone.0128065

59. Jayawardana, I.A., Montoya, C.A., McNabb, W.C., Boland, M.J. (2019). Possibility of minimizing gluten intolerance by coconsumption of some fruits - A case for positive food synergy? Trends in Food Science \& Technology, 94, 91-97. https://doi.org/10.1016/j.tifs.2019.10.003

60. Jouanin, A., Gilissen, L.J., Boyd, L.A., Cockram, J., Leigh, F.J., Wallington, E.J., van den Broeck, H.C., van der Meer, I.M., Schaart, J.G., Visser, R.G.F., Smulders, M.J.M. (2018). Food processing and breeding strategies for coeliac-safe and healthy wheat products. Food Research International, 110, 11-21. https://doi.org/10.1016/j.foodres.2017.04.025

61. Katina, K., Heiniö, R.L., Autio, K., Poutanen, K. (2006). Optimization of sourdough process for improved sensory profile and texture of wheat bread. LWT - Food Science and Technology, 39(10), 1189-1202.

https://doi.org/10.1016/j.Iwt.2005.08.001

62. Kaur, L., Rutherfurd, S.M., Moughan, P.J., Drummond, L., Boland, M.J. (2010). Actinidin enhances protein digestion in the small intestine as assessed using an in vitro digestion model. Journal of Agricultural and Food Chemistry, 58(8), 5074-5080. https://doi.org/10.1021/jf903835g

63. Kerpes, R., Knorr, V., Procopio, S., Koehler, P., Becker, T. (2016). Gluten-specific peptidase activity of barley as affected by germination and its impact on gluten degradation. Journal of Cereal Science, 68, 93-99. https://doi.org/10.1016/j.jcs.2016.01.004

64. King, J.A., Jeong, J., Underwood, F.E., Quan, J., Panaccione, N., Windsor, J.W., Ronksley, P., Shaheen, A.M., Quan, H., Van, S.V. (2020). Incidence of celiac disease is increasing over time: a systematic review and meta-analysis. American Journal of Gastroenterology, 115(4), 507-525.

https://doi.org/10.14309/ajg.0000000000000523

65. Kiyosaki, T., Asakura, T., Matsumoto, I., Tamura, T., Terauchi, K., Funaki, J., Kuroda M., Misaka T., Abe, K. (2009). Wheat cysteine proteases triticain $\alpha, \beta$ and $\gamma$ exhibit mutually distinct responses to gibberellin in germinating seeds. Journal of Plant Physiology, 166(1), 101-106.

https://doi.org/10.1016/j.jplph.2008.02.006

66. Knorr, V., Wieser, H., Koehler, P. (2016). Production of gluten-free beer by peptidase treatment. European Food Research and Technology, 242(7), 1129-1140.

https://doi.org/10.1007/s00217-015-2617-5

67. Krigel, A., Lebwohl, B. (2016). Nonceliac gluten sensitivity. Advances in Nutrition, 7(6), 1105-1110. https://doi.org/10.3945/an.116.012849

68. Kumar Mohan, B.V., Sarabhai, S., Prabhasankar, P. (2019). Targeted degradation of gluten proteins in wheat flour by prolyl endoprotease and its utilization in low immunogenic pasta for gluten sensitivity population. Journal of Cereal Science, 87, 59-67. https://doi.org/10.1016/j.jcs.2019.03.001

69. Kwiatkowska, B., Bennett, J., Akunna, J., Walker, G.M., Bremner, D.H. (2011). Stimulation of bioprocesses by ultrasound. Biotechnology Advances, 29(6), 768-780.

https://doi.org/10.1016/j.biotechadv.2011.06.005
70. Laatikainen, R., Koskenpato, J., Hongisto, S.M., Loponen, J., Poussa, T., Huang, X., Sontag-Strohm, T., Salmenkari, H., Korpela, R. (2017). Pilot study: Comparison of sourdough wheat bread and yeast-fermented wheat bread in individuals with wheat sensitivity and irritable bowel syndrome. Nutrients, 9(11), art no. 1215 .

https://doi.org/10.3390/nu9111215

71. Lamacchia, C., Landriscina, L., D’Agnello, P. (2016). Changes in wheat kernel proteins induced by microwave treatment. Food Chemistry, 197, 634-640.

https://doi.org/10.1016/j.foodchem.2015.11.016

72. Lerner, A., Matthias, T. (2015). Possible association between celiac disease and bacterial transglutaminase in food processing: a hypothesis. Nutrition Reviews, 73(8), 544-552. https://doi.org/10.1093/nutrit/nuv011

73. Leszczynska, J., Łącka, A., Szemraj, J., Lukamowicz, J., Zegota, H. (2003). The effect of microwave treatment on the immunoreactivity of gliadin and wheat flour. European Food Research and Technology, 217(5), 387-391. https://doi.org/10.1007/s00217-003-0765-5

74. Li, Y., Yu, J., Goktepe, I., Ahmedna, M. (2016). The potential of papain and alcalase enzymes and process optimizations to reduce allergenic gliadins in wheat flour. Food Chemistry, 196, 1338-1345.

https://doi.org/10.1016/j.foodchem.2015.10.089

75. Lionetti, E., Pulvirenti, A., Vallorani, M., Catassi, G., Verma, A.K., Gatti, S., Catassi, C. (2017). Re-challenge studies in non-celiac gluten sensitivity: a systematic review and meta-analysis. Frontiers in Physiology, 8, art no. 621.

https://doi.org/10.3389/fphys.2017.00621

76. Loponen, J., Sontag-Strohm, T., Venäläinen, J., Salovaara, H. (2007). Prolamin hydrolysis in wheat sourdoughs with differing proteolytic activities. Journal of Agricultural and Food Chemistry, 55(3), 978-984.

https://doi.org/10.1021/jf062755g

77. Lovegrove, A., Edwards, C.H., De Noni, I., Patel, H., El, S.N., Grassby, T., Zielke, CC., Ulmius, M., Nilsson, L., Butterworth, P.J., Ellis, P.R., Shewry, P.R. (2017). Role of polysaccharides in food, digestion, and health. Critical Reviews in Food Science and Nutrition, 57(2), 237-253.

https://doi.org/10.1080/10408398.2014.939263

78. Luongo, D., Maurano, F., Bergamo, P., Rossi, M. (2020). Microbial transglutaminase: A biotechnological tool to manage gluten intolerance. Analytical Biochemistry, 592, art. no. 113584. https://doi.org/10.1016/j.ab.2020.113584

79. Luz, C., D’Opazo, V., Mañes, J., Meca, G. (2019). Antifungal activity and shelf life extension of loaf bread produced with sourdough fermented by Lactobacillus strains. Journal of Food Processing and Preservation, 43(10), 1-8. https://doi.org/10.1111/jfpp.14126

80. Mahroug, H., Ribeiro, M., Rhazi, L., Bentallah, L., Zidoune, M.N., Nunes, F.M., Igrejas, G. (2019). How microwave treatment of gluten affects its toxicity for celiac patients? A study on the effect of microwaves on the structure, conformation, functionality and immunogenicity of gluten. Food Chemistry, 297, art. no. 124986.

https://doi.org/10.1016/j.foodchem.2019.124986

81. Mandile, R., Picascia, S., Parrella, C., Camarca, A., Gobbetti, M., Greco, L., Troncone, R., Gianfrani, C., Auricchio, R. (2017). 
Lack of immunogenicity of hydrolysed wheat flour in patients with coeliac disease after a short-term oral challenge. Alimentary Pharmacology \& Therapeutics, 46(4), 440-446.

https://doi.org/10.1111/apt.14175

82. Marino, M., Casale, R., Borghini, R., Di Nardi, S., Donato, G., Angeloni, A., Moscaritolo, S., Grasso, L., Mazzarella, G., Di Tola, M., Rossi, M., Picarelli, A. (2017). The effects of modified versus unmodified wheat gluten administration in patients with celiac disease. International Immunopharmacology, 47, 1-8. https://doi.org/10.1016/j.intimp.2017.03.012

83. Matthias, T., Jeremias, P., Neidhöfer, S., Lerner, A. (2016). The industrial food additive, microbial transglutaminase, mimics tissue transglutaminase and is immunogenic in celiac disease patients. Autoimmunity Reviews, 15(12), 1111-1119.

https://doi.org/10.1016/j.autrev.2016.09.011

84. Matysiak-Budnik, T., Candalh, C., Cellier, C., Dugave, C., Namane, A., Vidal-Martinez, T., Cerf-Bensussan, N., Heyman, M. (2005). Limited efficiency of prolyl-endopeptidase in the detoxification of gliadin peptides in celiac disease. Gastroenterology, 129(3), 786-796. https://doi.org/10.1053/j.gastro.2005.06.016

85. McAllister, B.P., Williams, E., Clarke, K. (2019). A comprehensive review of celiac disease/gluten-sensitive enteropathies. Clinical Reviews in Allergy \& Immunology, 57(2), 226-243.

https://doi.org/10.1007/s12016-018-8691-2

86. Meshram, A., Singhal, G., Bhagyawant, S.S., Srivastava, N. (2019). Plant-derived enzymes: a treasure for food biotechnology. In M. Kuddus (Ed.), Enzymes in Food Biotechnology, Academic Press, London, UK, pp. 483-502.

https://doi.org/10.1016/B978-0-12-813280-7.00028-1

87. Michalcová, E., Potocká, E., Chmelová, D., Ondrejovic, M. (2019). Study of wheat protein degradation during germination. The Journal of Microbiology, Biotechnology and Food Sciences, 1(6), 1437-1447.

88. Mickowska, B., Romanova, K., Socha, P., Urminska, D. (2018). Reduction of immunoreactivity of wheat and rye prolamins by Flavourzyme proteolysis. Journal of Food \& Nutrition Research, 57(3), 307-314.

89. Mika, N., Gorshkov, V., Spengler, B., Zorn, H., Rühl, M. (2015). Characterization of novel insect associated peptidases for hydrolysis of food proteins. European Food Research and Technology, 240(2), 431-439.

https://doi.org/10.1007/s00217-014-2342-5

90. Mitea, C., Havenaa, R., Drijfhout, J.W., Edens, L., Dekking, L., Koning, F. (2008). Efficient degradation of gluten by a prolyl endoprotease in a gastrointestinal model: implications for celiac disease. Gut, 57(1), 25-32.

https://doi.org/10.1136/gut.2006.111609

91. Montemurro, M., Pontonio, E., Gobbetti, M., Rizzello, C.G. (2019). Investigation of the nutritional, functional and technological effects of the sourdough fermentation of sprouted flours. International Journal of Food Microbiology, 302, 47-58.

https://doi.org/10.1016/j.ijfoodmicro.2018.08.005

92. Montserrat, V., Bruins, M.J., Edens, L., Koning, F. (2015). Influence of dietary components on Aspergillus niger prolyl endoprotease mediated gluten degradation. Food Chemistry, 174, 440-445.

https://doi.org/10.1016/j.foodchem.2014.11.053
93. Moreno Amador, M.D.L., Arévalo-Rodríguez, M., Durán, E.M., Martínez Reyes, J.C., Sousa Martín, C. (2019). A new microbial gluten-degrading prolyl endopeptidase: Potential application in celiac disease to reduce gluten immunogenic peptides. PLOS ONE, 14(6), art. no. e0218346.

https://doi.org/10.1371/journal. pone.0218346

94. Naqash, F., Gani, A., Gani, A., Masoodi, F.A. (2017). Gluten-free baking: Combating the challenges - A review. Trends in Food Science \& Technology, 66, 98-107.

https://doi.org/10.1016/j.tifs.2017.06.004

95. Navarro, V., Del Pilar Fernández-Gil, M., Simón, E., Bustamante, M.Á. (2017). Gluten: general aspects and international regulations for products for celiac people. In: J. Miranda, E. Simón. (Eds.). Nutritional and Analytical Approaches of Gluten-Free Diet in Celiac Disease, Springer, Cham, Switzerland, pp. 15-27. https://doi.org/10.1007/978-3-319-53342-1_2

96. Nionelli, L., Rizzello, C.G. (2016). Sourdough-based biotechnologies for the production of gluten-free foods. Foods, 5(3), art. no. 65 .

https://doi.org/10.3390/foods5030065

97. Patent application WO2006 / 097415, 2006. Mixture of at least 6 species of lactic acid bacteria and/or Bifidobacteria in the manufacture of sourdough.

98. Pellegrini, N., Agostoni, C. (2015). Nutritional aspects of gluten-free products. Journal of the Science of Food and Agriculture, 95(12), 2380-2385.

https://doi.org/10.1002/jsfa.7101

99. Pilon, F.M., Silva, C.D.R., Visôtto, L.E., Barros, R.D.A., da Silva Júnior, N.R., Campos, W.G., de Almeida Oliveira, M.G. (2017). Purification and characterization of trypsin produced by gut bacteria from Anticarsia gemmatalis. Archives of Insect Biochemistry and Physiology, 96(2), art. no. e21407. https://doi.org/10.1002/arch.21407

100. Rahaman, T., Vasiljevic, T., Ramchandran, L. (2016). Effect of processing on conformational changes of food proteins related to allergenicity. Trends in Food Science \& Technology, 49, 24-34. https://doi.org/10.1016/j.tifs.2016.01.001

101. Rashmi, B.S., Gayathri, D., Vasudha, M., Prashantkumar, C.S., Swamy, C.T., Sunil, K.S., Somaraja, P.K., Prakash, P., Prakash, P. (2020). Gluten hydrolyzing activity of Bacillus spp. isolated from sourdough. Microbial Cell Factories, 19(1), art. no. 130. https://doi.org/10.1186/s12934-020-01388-z

102. Ravee, R., Salleh, F.I.M., Goh, H.H. (2018). Discovery of digestive enzymes in carnivorous plants with focus on proteases. PeerJ, 6, art. no. e4914. https://doi.org/10.7717/peerj.4914

103. Rey, M., Yang, M., Lee, L., Zhang, Y., Sheff, J.G., Sensen, C.W., Mrazek, H., Halada, P., Man, P., McCarville, J.L., Verdu, E.F., Schriemer, D.C. (2016). Addressing proteolytic efficiency in enzymatic degradation therapy for celiac disease. Scientific Reports, 6, art. no. 30980.

https://doi.org/10.1038/srep30980

104. Rollan, G., De Angelis, M., Gobbetti, M., De Valdez, G.F. (2005). Proteolytic activity and reduction of gliadin-like fractions by sourdough lactobacilli. Journal of Applied Microbiology, 99(6), 1495-1502.

https://doi.org/10.1111/j.1365-2672.2005.02730.x

105. Romanová, K., Urminská, D. (2017). Potential of Lactobacillus plantarum CCM 3627 and Lactobacillus brevis CCM 1815 for 
fermentation of cereal substrates. Potravinarstvo Slovak Journal of Food Sciences, 11(1), 544-549.

https://doi.org/10.5219/696

106. Rutherfurd, S.M., Montoya, C.A., Zou, M.L., Moughan, P.J., Drummond, L.N., Boland, M.J. (2011). Effect of actinidin from kiwifruit (Actinidia deliciosa cv. Hayward) on the digestion of food proteins determined in the growing rat. Food Chemistry, 129(4), 1681-1689. https://doi.org/10.1016/j.foodchem.2011.06.031

107. Sakandar, H.A., Usman, K., Imran, M. (2018). Isolation and characterization of gluten-degrading Enterococcus mundtii and Wickerhamomyces anomalus, potential probiotic strains from indigenously fermented sourdough (Khamir). LWT - Food Science and Technology, 91, 271-277. https://doi.org/10.1016/j.lwt.2018.01.023

108. Salden, B.N., Monserrat, V., Troost, F.J., Bruins, M.J., Edens, L., Bartholomé, R., Haenen, G.R., Winkens, B., Koning, F., Masclee, A.A. (2015). Randomised clinical study: Aspergillus niger-derived enzyme digests gluten in the stomach of healthy volunteers. Alimentary Pharmacology \& Therapeutics, 42(3), 273-285.

https://doi.org/10.1111/apt.13266

109. Savvateeva, L.V., Gorokhovets, N.V., Makarov, V.A., Serebryakova, M.V., Solovyev, A.G., Morozov, S.Y., Reddy, V.P., Zernii, E.Y., Zamyatnin, A.A., Aliev, G. (2015). Glutenase and collagenase activities of wheat cysteine protease Triticain- $\alpha$ : feasibility for enzymatic therapy assays. The International Journal of Biochemistry \& Cell Biology, 62, 115-124. https://doi.org/10.1016/j.biocel.2015.03.001

110. Scherf, K.A., Wieser, H., Koehler, P. (2018). Novel approaches for enzymatic gluten degradation to create high-quality glutenfree products. Food Research International, 110, 62-72. https://doi.org/10.1016/j.foodres.2016.11.021

111. Schräder, C.U., Lee, L., Rey, M., Sarpe, V., Man, P., Sharma, S., Zabrouskov, V., Larsen, B., Schriemer, D.C. (2017). Nepro$\sin$, a selective prolyl endoprotease for bottom-up proteomics and histone mapping. Molecular \& Cellular Proteomics, 16(6), $1162-1171$.

https://doi.org/10.1074/mcp.M116.066803

112. Schulz, K., Giesler, L., Linke, D., Berger, R.G. (2018). A prolyl endopeptidase from Flammulina velutipes for the possible degradation of celiac disease provoking toxic peptides in cereal proteins. Process Biochemistry, 73, 47-55.

https://doi.org/10.1016/j.procbio.2018.07.019

113. Schwalb, T., Wieser, H., Koehler, P. (2012). Studies on the gluten-specific peptidase activity of germinated grains from different cereal species and cultivars. European Food Research and Technology, 235(6), 1161-1170.

https://doi.org/10.1007/s00217-012-1853-1

114. Siow, H.L., Choi, S.B., Gan, C.Y. (2016). Structure-activity studies of protease activating, lipase inhibiting, bile acid binding and cholesterol-lowering effects of pre-screened cumin seed bioactive peptides. Journal of Functional Foods, 27, 600-611. https://doi.org/10.1016/j.jff.2016.10.013

115. Socha, P., Mickowska, B., Urminská, D., Kacmárová, K. (2015). The use of different proteases to hydrolyze gliadins. The Journal of Microbiology, Biotechnology and Food Sciences, 4, 101-104. https://doi.org/10.15414/jmbfs.2015.4.special2.101-104
116. Stănciuc, N., Banu, I., Bolea, C., Patraşcu, L., Aprodu, I. (2018). Structural and antigenic properties of thermally treated gluten proteins. Food Chemistry, 267, 43-51. https://doi.org/10.1016/j.foodchem.2017.03.018

117. Standard 118-1979. Codex Standard for foods for special dietary use for persons intolerant to gluten. Codex Alimentarius Commission. Revision 2015, 1. [http://www.codexalimentarius. net/download/standards/291/cxs_118e.pdf].

118. Stantiall, S.E., Serventi, L. (2018). Nutritional and sensory challenges of gluten-free bakery products: a review. International Journal of Food Sciences and Nutrition, 69(4), 427-436. https://doi.org/10.1080/09637486.2017.1378626

119. Stazi, A.V., Trinti, B. (2008). Selenium deficiency in celiac disease: risk of autoimmune thyroid diseases. Minerva Medica, 99(6), 643-653.

120. Stefańska, I., Piasecka-Jóźwiak, K., Kotyrba, D., Kolenda, M., Stecka, K.M. (2016). Selection of lactic acid bacteria strains for the hydrolysis of allergenic proteins of wheat flour. Journal of the Science of Food \& Agriculture, 96(11), 3897-3905.

https://doi.org/10.1002/jsfa.7588

121. Stenman, S.M., Venäläinen, J.I., Lindfors, K., Auriola, S., Mauriala, T., Kaukovirta-Norja, A., Jantunen, A., Laurila, K., Qiao, S.W., Sollid, L.M., Männistö P.T., Kaukinen, K. Mäki, M. (2009). Enzymatic detoxification of gluten by germinating wheat proteases: implications for new treatment of celiac disease. Annals of Medicine, 41 (5), 390-400. https://doi.org/10.1080/07853890902878138

122. Stepniak, D., Spaenij-Dekking, L., Mitea, C., Moester, M., de Ru, A., Baak-Pablo, R., van Veelen, P., Edens L., Koning, F. (2006). Highly efficient gluten degradation with a newly identified prolyl endoprotease: implications for celiac disease. American Journal of Physiology-Gastrointestinal and Liver Physiology, 291(4), G621-G629.

https://doi.org/10.1152/ajpgi.00034.2006

123. Sun, L., Li, X., Zhang, Y., Yang, W., Ma, G., Ma, N., Hu, Q., Pei, F. (2020). A novel lactic acid bacterium for improving the quality and shelf life of whole wheat bread. Food Control, 109, art. no. 106914.

https://doi.org/10.1016/j.foodcont.2019.106914

124. Sun, Q., Zhang, B., Yan, Q.J., Jiang, Z.Q. (2016). Comparative analysis on the distribution of protease activities among fruits and vegetable resources. Food Chemistry, 213, 708-713. https://doi.org/10.1016/j.foodchem.2016.07.029

125. Taga, Y., Hayashida, O., Kusubata, M., Ogawa-Goto, K., Hattori, S. (2017). Production of a novel wheat gluten hydrolysate containing dipeptidyl peptidase-IV inhibitory tripeptides using ginger protease. Bioscience, Biotechnology and Biochemistry, 81(9), 1823-1828. https://doi.org/10.1080/09168451.2017.1345615

126. Tanveer, M., Ahmed, A. (2019). Non-celiac gluten sensitivity: A systematic review. Journal of the College of Physicians and Surgeons Pakistan, 29(1), 51-57.

https://doi.org/10.29271/jcpsp.2019.01.51

127. Tavano, O.L., Berenguer-Murcia, A., Secundo, F., Fernandez-Lafuente, R. (2018). Biotechnological applications of proteases in food technology. Comprehensive Reviews in Food Science and Food Safety, 17(2), 412-436. https://doi.org/10.1111/1541-4337.12326 
128. Tereshchenkova, V.F., Goptar, I.A., Kulemzina, I.A., Zhuzhikov, D.P., Serebryakova, M.V., Belozersky, M.A., Dunaevsky, Y.E., Oppert, B., Filippova, I.Y., Elpidina, E.N. (2016). Dipeptidyl peptidase 4 - an important digestive peptidase in Tenebrio molitor larvae. Insect Biochemistry and Molecular Biology, 76, 38-48. https://doi.org/10.1016/j.ibmb.2016.07.003

129. Thiele, C., Grassl, S., Gänzle, M. (2004). Gluten hydrolysis and depolymerization during sourdough fermentation. Journal of Agricultural and Food Chemistry, 52(5), 1307-1314. https://doi.org/10.1021/jf034470z

130. Thomason, W.E., Hughes, K.R., Griff, C.A., Parrish, D.J., Barbeau, W.E. (2019). Understanding pre-harvest sprouting of wheat. Publications, Virginia Cooperative Extension, 424, 424-060.

131. Toft-Hansen, H., Rasmussen, K.S., Staal, A., Roggen, E.L., Sollid, L.M., Lillevang, S.T., Barington, T., Husby, S. (2014). Treatment of both native and deamidated gluten peptides with an endo-peptidase from Aspergillus niger prevents stimulation of gut-derived gluten-reactive $\mathrm{T}$ cells from either children or adults with celiac disease. Clinical Immunology, 153(2), 323-331. https://doi.org/10.1016/j.clim.2014.05.009

132. Tran, C.D., Katsikeros, R., Manton, N., Krebs, N.F., Hambidge, K.M., Butler, R.N., Davidson, G.P. (2011). Zinc homeostasis and gut function in children with celiac disease. The American Journal of Clinical Nutrition, 94, 1026-1032. https://doi.org/10.3945/ajcn.111.018093

133. Vermeulen, N., Kretzer, J., Machalitza, H., Vogel, R.F., Gänzle, M.G. (2006). Influence of redox-reactions catalysed by homoand hetero-fermentative lactobacilli on gluten in wheat sourdoughs. Journal of Cereal Science, 43(2), 137-143. https://doi.org/10.1016/j.jcs.2005.08.006

134. Vici, G., Belli, L., Biondi, M., Polzonetti, V. (2016). Gluten free diet and nutrient deficiencies: A review. Clinical Nutrition, 35(6), 1236-1241. https://doi.org/10.1016/j.clnu.2016.05.002

135. Vukotić, G., Strahinić, I., Begović, J., Lukić, J., Kojić, M., Fira, D. (2016). Survey on proteolytic activity and diversity of proteinase genes in mesophilic lactobacilli. Microbiology, 85(1), $33-41$. https://doi.org/10.1134/S002626171601015X

136. Walter, T., Wieser, H., Koehler, P. (2014). Production of gluten-free wheat starch by peptidase treatment. Journal of Cereal Science, 60(1), 202-209. https://doi.org/10.1016/j.jcs.2014.02.012

137. Wang, J.S., Zhao, M.M., Zhao, Q.Z., Jiang, Y.M. (2007). Antioxidant properties of papain hydrolysates of wheat gluten in different oxidation systems. Food Chemistry, 101(4), 1658-1663. https://doi.org/10.1016/j.foodchem.2006.04.024

138. Watanabe, M., Watanabe, J., Sonoyama, K., Tanabe, S. (2000). Novel method for producing hypoallergenic wheat flour by enzymatic fragmentation of the constituent allergens and its application to food processing. Bioscience, Biotechnology, and Biochemistry, 64(12), 2663-2667. https://doi.org/10.1271/bbb.64.2663
139. Wieser, H., Koehler, P. (2012). Detoxification of gluten by means of enzymatic treatment. Journal of AOAC International, 95(2), 356-363.

https://doi.org/10.5740/jaoacint.SGE_Wieser

140. Wolf, C., Siegel, J.B., Tinberg, C., Camarca, A., Gianfrani, C., Paski, S., Guan, R., Montelione, G., Baker, D., Pultz, I.S. (2015). Engineering of Kuma030: a gliadin peptidase that rapidly degrades immunogenic gliadin peptides in gastric conditions. Journal of the American Chemical Society, 137(40), 13106-13113.

https://doi.org/10.1021/jacs.5b08325

141. Xue, L., Li, Y., Li, T., Pan, H., Liu, J., Fan, M., Qian, H., Zhang, H., Ying, H., Wang, L. (2019). Phosphorylation and enzymatic hydrolysis with alcalase and papain effectively reduce allergic reactions to gliadins in normal mice. Journal of Agricultural and Food Chemistry, 67(22), 6313-6323.

https://doi.org/10.1021/acs.jafc.9b00569

142. Yang, X., Li, Y., Li, S., Oladejo, A.O., Wang, Y., Huang, S., Zhou, C., Wang, Y., Mao, Li., Zhang, Y., Ma, H., Ye, X. (2017). Effects of multi-frequency ultrasound pretreatment under low power density on the enzymolysis and the structure characterization of defatted wheat germ protein. Ultrasonics Sonochemistry, 38, 410-420. https://doi.org/10.1016/j.ultsonch.2017.03.001

143. Yin, Y., Wang, J., Yang, S., Feng, J., Jia, F., Zhang, C. (2015). Protein degradation in wheat sourdough fermentation with Lactobacillus plantarum M616. Interdisciplinary Sciences: Computational Life Sciences, 7(2), 205-210. https://doi.org/10.1007/s12539-015-0262-0

144. Yoosuf, S., Makharia, G.K. (2019). Evolving therapy for celiac disease. Frontiers in Pediatrics, 7, art. no. 193. https://doi.org/10.3389/fped.2019.00193

145. Yu, Z.L., Zeng, W.C., Zhang, W.H., Liao, X.P., Shi, B. (2014). Effect of ultrasound on the activity and conformation of $\alpha$-amylase, papain and pepsin. Ultrasonics Sonochemistry, 21(3), 930-936.

https://doi.org/10.1016/j.ultsonch.2013.11.002

146. Zhang, H., Claver, I.P., Zhu, K.X., Zhou, H. (2011). The effect of ultrasound on the functional properties of wheat gluten. $\mathrm{Mol}$ ecules, 16(5), 4231-4240.

https://doi.org/10.3390/molecules16054231

147. Zhang, Y., Ma, H., Wang, B., Qu, W., Li, Y., He, R., Wali, A. (2015). Effects of ultrasound pretreatment on the enzymolysis and structural characterization of wheat gluten. Food Biophysics, 10(4), 385-395.

https://doi.org/10.1007/s11483-015-9393-4

148. Zhou, L., Wu, Y., Cheng, Y., Wang, J., Lu, J., Gao, J., Yuan, J., Chen, H. (2017). Blocking celiac antigenicity of the glutaminerich gliadin 33-mer peptide by microbial transglutaminase. $R S C$ Advances, 7(24), 14438-14447.

https://doi.org/10.1039/C6RA27893K

Submitted: 20 November 2020. Revised: 12 January 2021. Accepted: 26 January 2021. Published on-line: 12 February 21. 